\title{
Modeling agriculture in the Community Land Model
}

\author{
B. Drewniak ${ }^{1}$, J. Song ${ }^{2}$, J. Prell ${ }^{1}$, V. R. Kotamarthi ${ }^{1}$, and R. Jacob ${ }^{3}$ \\ ${ }^{1}$ Environmental Science Division, Argonne National Laboratory, 9700 S. Cass Ave, Argonne, IL 60439, USA \\ ${ }^{2}$ Northern Illinois University, Department of Geography, Davis Hall, Room 118, DeKalb, IL 60115, USA \\ ${ }^{3}$ Mathematics and Computer Science Division, Argonne National Laboratory, 9700 S. Cass Ave, Argonne, IL 60439, USA \\ Correspondence to: B. Drewniak (bbye@anl.gov)
}

Received: 29 October 2012 - Published in Geosci. Model Dev. Discuss.: 11 December 2012

Revised: 22 March 2013 - Accepted: 26 March 2013 - Published: 19 April 2013

\begin{abstract}
The potential impact of climate change on agriculture is uncertain. In addition, agriculture could influence above- and below-ground carbon storage. Development of models that represent agriculture is necessary to address these impacts. We have developed an approach to integrate agriculture representations for three crop types - maize, soybean, and spring wheat - into the coupled carbon-nitrogen version of the Community Land Model (CLM), to help address these questions. Here we present the new model, CLMCrop, validated against observations from two AmeriFlux sites in the United States, planted with maize and soybean. Seasonal carbon fluxes compared well with field measurements for soybean, but not as well for maize. CLM-Crop yields were comparable with observations in countries such as the United States, Argentina, and China, although the generality of the crop model and its lack of technology and irrigation made direct comparison difficult. CLM-Crop was compared against the standard CLM3.5, which simulates crops as grass. The comparison showed improvement in gross primary productivity in regions where crops are the dominant vegetation cover. Crop yields and productivity were negatively correlated with temperature and positively correlated with precipitation, in agreement with other modeling studies. In case studies with the new crop model looking at impacts of residue management and planting date on crop yield, we found that increased residue returned to the litter pool increased crop yield, while reduced residue returns resulted in yield decreases. Using climate controls to signal planting date caused different responses in different crops. Maize and soybean had opposite reactions: when low temperature threshold resulted in early planting, maize responded with a loss of yield, but soybean yields increased. Our improvements in CLM demonstrate a new capability in
\end{abstract}

the model - simulating agriculture in a realistic way, complete with fertilizer and residue management practices. Results are encouraging, with improved representation of human influences on the land surface and the potentially resulting climate impacts.

\section{Introduction}

The role of agriculture in the biosphere has important implications for climate change. Humans have influenced 42$68 \%$ of the land surface (Hurtt et al., 2006) through activities related to cultivation, wood harvesting, and grazing. Globally, around $12 \%$ of the land is currently used for agriculture, and in the United States cultivation accounts for roughly $20 \%$ of the land base (http://faostat.fao.org). Even though these numbers represent a significant area of land, most Earth system models either ignore agriculture or represent cultivation in a simplistic way without management or harvest activities.

Climate change can have a significant impact on crop yields. Increasing demand for agricultural products from increasing worldwide population places changes in crop yields at the center of climate change impacts on human societies (Parry et al., 2004; Fischer et al., 2005). Past studies have shown that increased temperatures and extreme precipitation events have a negative impact on yield for some crops (Rosenzweig et al., 2002; Lobell and Field, 2007; Osborne et al., 2009; Schlenker and Roberts, 2009; Lobell et al., 2011), offsetting some of the technological advances in crop development (Lobell and Field, 2007; Lobell et al., 2011). Urban et al. (2012) predicted that future climate variability could be responsible for a decreasing trend of crop yields and an 
increase in yield variability, although some variability might be mitigated through adaptation strategies.

Agriculture can also have a significant influence on climate change through biophysical responses to surface fluxes of $\mathrm{CO}_{2}$ and NOx, albedo, and heat fluxes, as well as biochemical responses from soil carbon cycling. For example, irrigation and reduced tillage on croplands resulted in a global cooling effect, while local effects for precipitation, cloud cover, and radiation were stronger (Lobell et al., 2006; Diffenbaugh, 2009).

Cultivation also impacts the carbon stored and released from soil. Loss of soil carbon as a result of native vegetation removal can be significant, with long payback times (Fargione et al., 2008; Gibbs et al., 2008; Searchinger et al., 2008). The influence of crops on carbon cycling varies with management practices such as crop rotation, tillage, fertilizer inputs, and residue harvesting (West and Post, 2002; Hooker et al., 2005; Dou and Hons, 2006; Huggins et al., 2007; Khan et al., 2007; Kim et al., 2009). Although observations disagree on the magnitude and in some cases the sign of carbon change, most do agree that management influences the total soil carbon stored.

The strong atmosphere-land surface coupling and the pronounced influence of agriculture on the biosphere make the inclusion of crops important and necessary for evaluating atmosphere-biosphere interactions. As the need for improved land surface models and the importance of disturbance on biogeochemical cycles were recognized, new models that include agriculture began to emerge. Several studies have incorporated agriculture into a vegetation modeling framework to improve estimates of carbon and nitrogen cycling in the soil system (Kucharik and Brye, 2003; Bondeau et al., 2007; Osborne et al., 2007; Smith et al., 2010; Levis et al., 2012). Agro-IBIS (Agro-Integrated Biosphere Simulator; Kucharik and Brye, 2003), which was designed to simulate maize, soybean, and wheat crop types across the continental United States, has been tested against flux measurements (Kucharik and Twine, 2007). Agro-IBIS was used to evaluate yield variability against nitrogen inputs (Kucharik and Brye, 2003) and planting date (Kucharik, 2008) and has undergone yield sensitivity analysis (Kucharik, 2003). The LPJ-mL (Lund-Potsdam-Jenna-managed land; Bondeau et al., 2007) agriculture model combines a dynamic vegetation model with several crop types, represented much like natural vegetation through the use of crop functional types. This allows the model to capture growth on a global scale. LPJ$\mathrm{mL}$ was used to evaluate future water and carbon fluxes as a result of land use change, management, and $\mathrm{CO}_{2}$ fertilization. Although LPJ-mL does include a fertilizer representation through influences on leaf area index (LAI), the model does not include nutrient cycling, which might impact plant development as a result of nitrogen stress. Osborne et al. (2007) developed a coupled crop-climate model to evaluate the influence of crops on climate by incorporating the General Large Area Model (GLAM), a groundnut model that can be applied to other tropical crop types, into the Hadley Center Atmospheric Model (HadAM3). The focus of the study was in the tropics, using temperature and soil moisture to interactively determine crop management such as cultivation area, sowing date, and growing season. Osborne et al. (2009) noted the correlation between climate and crop yield variability and additionally found that crop yield variability had an impact on temperature, though not necessarily on precipitation. The ORCHIDEE-STICS (Organizing Carbon and Hydrology in Dynamic Ecosystems-Supra-Thermal Ion Composition Spectrometer; Smith et al., 2010) model focuses on the European crops soybean, maize, and winter wheat and uses an automated fertilizer and irrigation scheme when plants become stressed, but it does not include explicit crop organ development and residue management.

Recently, a more sophisticated crop model was incorporated into the Community Land Model (Levis et al., 2012). This addition adds a separate growth scheme for crops to simulate maize, soybean, and cereals in the midlatitudes, using algorithms from the Agro-IBIS model (Kucharik and Brye, 2003). Levis et al. (2012) used the new development to evaluate $\mathrm{CO}_{2}$ fluxes from the modified LAI. The model showed promising improvements in annual net ecosystem exchange and the impact agriculture has on climate, such as reduced precipitation. However, this model lacked some important features of nitrogen cycling (nitrogen retranslocation, soybean nitrogen fixation) and management practices (fertilizer, residue harvest) that may have an important impact on the carbon fluxes.

We chose the coupled carbon-nitrogen version of the Community Land Model (CLM [CLM-CN]; Thornton and Zimmerman, 2007; Oleson et al., 2008; Stockli et al., 2008) as a basis for our model, because CLM-CN already had a comprehensive carbon-nitrogen scheme, allowed multiple plant functional types (PFTs) to exist within a grid cell, and integrated crops as a model component (although they were represented as grass). In addition, CLM-CN was already coupled to the atmosphere and ocean in the Community Climate System Model version 3 (CCSM3.0) and beyond, providing an opportunity for future studies on feedbacks between climate change and agricultural productivity. We expanded the PFTs in CLM-CN to include specific crop types, allowing them to share space but exist separately, so as not to compete for resources with natural vegetation. Our new model, CLM-Crop, presented in this paper, includes new physiology and carbon schemes to describe maize, soybean, and spring wheat. We investigate the ability of CLM-Crop to simulate agriculture environments through calculated harvest yields, LAI, and gross primary productivity (GPP). In addition, we include a capability for varying residue management and fertilizer. We do not consider tillage practices, because CLMCrop's carbon pools are not distributed in the soil profile. We note that although CLM-Crop is designed to be implemented globally, a majority of the parameterizations are typical of crops grown in the United States; therefore we focus 
our analysis on this region, with some limited discussion on the global results.

Several features of CLM-Crop will be included in the next release of CLM; we will point out those features throughout the model development section. The description of CLMCrop in Sect. 2 includes a breakdown of the simulations performed. Section 3 evaluates the model's performance through comparison with observations and a standard grass simulation. Next, case studies demonstrate the impact of residue management and planting date on yield and GPP in Sect. 4. A discussion follows in Sect. 5.

\section{Methods}

\subsection{Description of the Crop Module (CLM-Crop)}

The standard CLM3.5, which simulates land surface response to climate forcing, has been tested extensively against observations, both as a component of the CCSM3.0 and offline (Oleson et al., 2008; Stockli et al., 2008). The CLM optional feature to include carbon and nitrogen cycling (CLMCN) was discussed by Thornton and Zimmerman (2007). However, crops in CLM-CN are generic, modeled as grasses without biomass removal during harvest and without varied carbon allocation during different growth stages. Therefore, we have added three additional PFTs to the model to represent maize, soybean, and spring wheat crop types. We began our evaluation with these three types, because (1) maize occupies that largest share of cultivated land in North America, with the expectation of an even larger share in the future as a major ethanol fuel source; (2) soybean is the second largest crop cultivated in North America, grows rapidly in South America, and is a potential biodiesel crop; and (3) spring wheat is the primary cereal crop produced all over the world. All three crops have been studied extensively and have known phenology.

CLM-Crop has a sub-grid hierarchy allowing multiple PFTs to exist in a single soil column and multiple soil columns to exist in a grid cell (Fig. 1). Each soil column has its own carbon and nitrogen pools, so vegetation growing in one column does not compete for resources with vegetation in a separate column. We separate crops from natural vegetation to model them independently. For example, a grid cell growing maize and soybean in addition to natural trees and grasses will have at least three soil columns: one containing natural vegetation PFTs, one containing maize, and one containing soybean. Although they share the space on a grid cell, each soil column has separate dynamics for soil water, litter, soil organic carbon, etc., consistent with the vegetation in that column.

\subsubsection{Growth scheme}

The growth and development processes of crops are broken into four stages (similar to Levis et al., 2012): seeding,

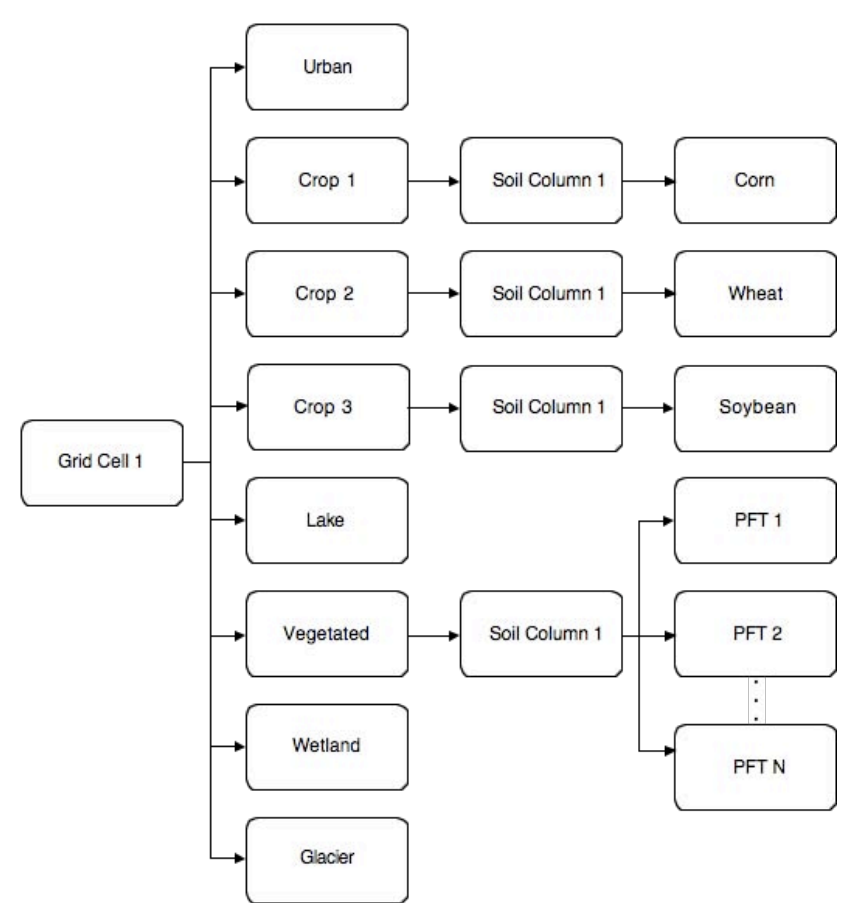

Fig. 1. An example of the sub-grid hierarchy in CLM-Crop (based on concepts of Oleson et al., 2004).

emergence, organ development, and harvest. Each phase is characterized by varied carbon allocation between the components of the plant: leaves, stems, roots, and grain. The growth stage is determined by the fraction of phenological heat units (FPHUs) accumulated (Table 1), relative to the crop planting date. The FPHUs for each growth stage are similar to those in the Agro-IBIS model (Kucharik and Brye, 2003). FPHUs are calculated as

FPHU $=\frac{\sum_{i=\text { planting }}^{\text {current day }} \mathrm{HU}_{i}}{\text { PHU }}$,

where PHU is the total number of phenological heat units (PHUs) necessary to reach maturity. At planting, heat units (HUs) are accumulated daily as

$\mathrm{HU}=T_{\text {ave }}-T_{\text {base }}$,

where $T_{\text {ave }}$ is the average $2 \mathrm{~m}$ air temperature for the current day, and $T_{\text {base }}$ is the minimum temperature required for growth, as in the SWAT (Soil Water Assessment Tool) model (Neitsch et al., 2005). The total number of PHUs necessary to reach maturity, derived by the Sacks et al. (2010) Crop Calendar Dataset, varies spatially and with crop species (described in Sect. 2.2). PHUs were originally calculated from a base temperature of $5^{\circ} \mathrm{C}$, so we use $5^{\circ} \mathrm{C}$ as a base temperature for all crops. Because growth stages for plant development are determined by the fraction of total PHUs, this approach is reasonable, even though actual base 
temperature is $0{ }^{\circ} \mathrm{C}$ for spring wheat and ranges from 8 to $10^{\circ} \mathrm{C}$ for maize and soybean. For grid cells where PHU data are not included in the Crop Calendar Dataset, a default PHU value is used (Table 1).

The planting date is fixed for each crop and is based on the average planting date from Sacks et al. (2010). At planting, small amounts of carbon (approximately equivalent to the carbon content in seeds) and nitrogen (Table 1) are allocated to the leaves to initiate photosynthesis for growth, but further carbon allocation is withheld until the crop has reached the emergence phase. The fraction of available carbon allocated hourly to each plant component (leaves, roots, and stems) during the remaining growth period follows the Agro-IBIS model (Kucharik and Brye, 2003), as was also done by Levis et al. (2012). Between emergence and organ development, carbon is directed toward leaves, roots, and stems. Root development assimilates $30-50 \%$ of carbon initially; this value decreases with PHU accumulation to $5 \%$ by maturity (Table 1), while the remaining carbon is allocated to leaves and stems.

Once organ development begins, carbon directed to leaves and stems decreases rapidly, and the majority of carbon is appropriated to grain, while a small amount is filtered to the roots (Table 1). Throughout the growth period, photosynthesis is limited by the availability of water and nitrogen through a downregulation process. The grain fill features of this model differ from the Levis et al. (2012) crop model through the maintenance of a separate pool for organ carbon and nitrogen to keep track of yield, whereas Levis et al. (2012) allocate grain carbon into the stem pool.

\subsubsection{Nitrogen and retranslocation}

Nitrogen allocation for crops follows that of natural vegetation, which is based on carbon:nitrogen $(\mathrm{CN})$ ratios for leaves, stems, roots, organs, and litter. Nitrogen demand during organ development is fulfilled through retranslocation from leaves, stems, and roots (Pollmer et al., 1979; Crawford et al., 1982; Simpson et al., 1983; Ta and Weiland, 1992; Barbottin et al., 2005; Gallais et al., 2006, 2007). Because most $\mathrm{CN}$ ratio measurements are from mature crops, we established pre- and post-grain-development $\mathrm{CN}$ ratios for leaves, stems, and roots (Table 1). Prior to organ development, $\mathrm{CN}$ ratios are optimized to allow maximum nitrogen accumulation for later use during organ development. When grain fill begins, nitrogen from the leaves, stems, and roots (for wheat) is transferred to a retranslocation pool, such that the new $\mathrm{CN}$ ratio for each plant part is the same as for crop residue. The organ nitrogen demand is first supplied from the retranslocated nitrogen pool, and any remaining demand is drawn from the soil nitrogen pools. The retranslocation scheme is included in the next release of CLM4.5.

\subsubsection{Fertilization}

In CLM, the denitrification rate is high, resulting in a $50 \%$ loss of the unused available nitrogen each day. To integrate fertilizer into the model without significant loss of fertilizer during the early stages of growth when nitrogen demand is low and availability is high, we adopted a fertilizer scheme delivering nitrogen directly to the soil mineral nitrogen pool over a 20 day period, beginning at emergence. The scheme can effectively reduce large losses of nitrogen due to leaching and denitrification during the early stage of crop development. The 20 day period was chosen as an optimization tool to limit fertilizer application to the emergence stage. Total nitrogen fertilizer amounts are $150 \mathrm{~kg} \mathrm{ha}^{-1}$ for maize, $80 \mathrm{~kg} \mathrm{ha}^{-1}$ for wheat, and $25 \mathrm{~kg} \mathrm{ha}^{-1}$ for soybean, representative of current annual fertilizer application rates in the United States (http://www.ers.usda.gov/Data/FertilizerUse). The fertilizer scheme is included for the release of CLM4.5.

\subsubsection{Soybean nitrogen fixation}

Nitrogen fixation by soybean is similar to that in the SWAT model (Neitsch et al., 2005) and is dependent on soil moisture, nitrogen availability, and growth stage. If soil nitrogen is sufficient to meet soybean demand, no fixation will occur during the time step. Nitrogen fixation is largest during the early to middle growth stages, when demand for nitrogen is greatest. Soybean fixation is dependent on soil water, nitrogen availability, and the growth stage of the crop, determined by

$N_{\text {fix }}=N_{\text {plant_ndemand }} * \min (1, f x w, f x n) * f x g$,

where $N_{\text {plant_ndemand }}$ is the balance of nitrogen needed to reach potential growth that cannot be supplied from the soil mineral nitrogen pool, $f x w$ is the soil water factor, $f x n$ is the soil nitrogen factor, and $f x g$ is the growth stage factor calculated by

$f x w=\frac{w f}{0.85}$,

$f x n=\left\{\begin{array}{cl}0 & \text { for sminn } \leq 10 \\ 1.5-0.005 *(\operatorname{sminn} * 10) & \text { for } 10<\operatorname{sminn} \geq 30 \\ 1 & \text { for } \operatorname{sminn}>30\end{array}\right.$

$f x g=\left\{\begin{array}{cl}0 & \text { for } \mathrm{PHU} \leq 0.15 \\ 6.67 * \mathrm{PHU}-1 & \text { for } 0.15<\mathrm{PHU} \geq 0.30 \\ 1 & \text { for } 0.30<\mathrm{PHU} \geq 0.55 \\ 3.75-5 * \mathrm{PHU} & \text { for } 0.55<\mathrm{PHU} \geq 0.75 \\ 0 & \text { for } \mathrm{PHU} \geq 0.75\end{array}\right.$

where $w f$ is the soil water content as a fraction of the waterholding capacity for the top $0.5 \mathrm{~m}$, sminn is the total nitrogen in the soil pool $\left(\mathrm{g} \mathrm{m}^{-2}\right)$, and PHU is the fraction of growing degree days accumulated during the growth period. $N_{\text {fix }}$ is 
Table 1. Crop parameters.

\begin{tabular}{|c|c|c|c|}
\hline Parameter & Maize & Wheat & Soybean \\
\hline \multicolumn{4}{|l|}{ FPHUs for growth stages } \\
\hline Seeding & 0 & 0 & 0 \\
\hline Emergence & 0.03 & 0.08 & 0.03 \\
\hline Grain fill & 0.53 & 0.59 & 0.70 \\
\hline Harvest & 1 & 1 & 1 \\
\hline \multicolumn{4}{|l|}{ Pre-grain-fill-stage $\mathrm{CN}$ ratio } \\
\hline Leaf & 10 & 15 & 25 \\
\hline Stem & 50 & 50 & 50 \\
\hline Root & 42 & 30 & 42 \\
\hline Organ & 50 & 40 & 60 \\
\hline \multicolumn{4}{|l|}{ Post-grain-fill-stage $\mathrm{CN}$ ratio } \\
\hline Leaf & 65 & 65 & 65 \\
\hline Stem & 120 & 100 & 130 \\
\hline Root & 42 & 40 & 42 \\
\hline Organ & 50 & 40 & 60 \\
\hline \multicolumn{4}{|l|}{ Other parameters } \\
\hline Base temperature & $5^{\circ} \mathrm{C}$ & $5^{\circ} \mathrm{C}$ & $5^{\circ} \mathrm{C}$ \\
\hline Initial carbon allocation to seed $\left(\mathrm{g} \mathrm{C} \mathrm{m}^{-2}\right)$ & 0.8 & 3.9 & 2.5 \\
\hline Initial root carbon allocation & $40 \%$ & $30 \%$ & $50 \%$ \\
\hline Initial leaf carbon allocation & \multicolumn{3}{|c|}{ Depends on FPHU } \\
\hline Initial stem carbon allocation & \multicolumn{3}{|c|}{ Depends on FPHU } \\
\hline Final root carbon allocation & $5 \%$ & $5 \%$ & $5 \%$ \\
\hline Final leaf carbon allocation & $0 \%$ & $0 \%$ & $0 \%$ \\
\hline Final stem carbon allocation & $5 \%$ & $5 \%$ & $5 \%$ \\
\hline Maximum LAI & 5.0 & 7.0 & 6.0 \\
\hline Maximum harvest index & 0.6 & 0.5 & 0.38 \\
\hline Default PHU & 1600 & 1900 & 1000 \\
\hline Maximum root depth (m) & 1.2 & 0.9 & 1.6 \\
\hline
\end{tabular}

added directly to the soil mineral nitrogen pool for use in that time step. Nitrogen fixation does not occur in the early growth stage, before the plant accumulates $15 \%$ of PHU, or in the late growth stage, after $75 \%$ of PHUs have accrued (shortly after grain fill begins). The soybean fixation scheme will also be added to the CLM4.5 crop model.

\subsubsection{Crop root structure}

In CLM-CN, vegetation has a constant root depth and density profile; root density decreased linearly with depth. In Levis et al. (2012), root density for all vegetation decreased exponentially with depth, but for crops it did not vary with growth. We incorporated into CLM-Crop a dynamic root scheme to approximate fine root distribution and rooting depth in response to environmental conditions.

The root depth for natural vegetation is held constant and is dependent on the type of PFT (Oleson et al., 2004). Crops have a dynamic rooting depth that depends on growth stage. Crop root depth, which is $4 \mathrm{~cm}$ at planting, continues to grow linearly with FPHU until a maximum depth is reached at the beginning of the organ development stage. The gradual increase in root depth is meant to simulate a young crop withstanding dry soil profiles. Maximum root depths for maize, wheat, and soybean are $120 \mathrm{~cm}, 90 \mathrm{~cm}$, and $160 \mathrm{~cm}$, respectively (Mayaki et al., 1976; Araki and Iijima, 2001; Amos and Walters, 2006).

The fine root carbon budget in each soil layer depends on new carbon allocation and turnover loss at each time step. Fine root carbon, $C_{i}\left(\mathrm{~kg} \mathrm{~m}^{-2}\right)$, in each soil layer $(i)$ is calculated as

$C_{i}=C_{i, 0}+r_{d, i} C_{\text {new }}-R_{i} C_{\text {loss }}$,

where

$r_{d, i}=(1-f) r_{w, i}+f r_{n, i}$.

The new carbon $\left(C_{\text {new }}\right)$ allocation is based on a redistribution factor $\left(r_{d, i}\right)$ for each soil layer that links soil moisture and nutrient uptake capacity by weighting the relative available soil moisture $\left(r_{w, i}\right)$ and the relative nutrient distribution 
$\left(r_{n, i}\right)$ by the root zone water availability factor $(f)$, where $f$ ranges from 0 for soil at the wilting point to 1 for saturated soil. The distribution algorithm for new fine roots combines the availability of two essential substances - water and nutrients - for root uptake and allows for root plasticity with non-uniform water distribution (Mayaki et al., 1976; Garay and Wilhelm, 1983; Amos and Walter, 2006). Carbon loss $\left(C_{\text {loss }}\right)$ due to root turnover is removed from each layer relative to the fine root fraction $\left(R_{i}\right)$ in the soil layer.

The prescribed relative nutrient profile used to calculate $r_{n, i}$ is the approximated nitrogen profile based on Jobbagy and Jackson (2001) and the global soil profile data set of Batjes (2008). This profile has constant nitrogen in the top soil layers (less than $10 \mathrm{~cm}$ depth), decreasing linearly to zero at the bottom of the last soil layer. This distribution is characteristic of agricultural soils where past tillage practices have homogenized the upper soil profiles (Blanco-Canqui and Lal, 2008).

\subsubsection{Harvest management}

Crops are harvested as soon as maturity is reached, as was done by Levis et al. (2012). However, in CLM-Crop, harvest is partitioned between the atmosphere and litter pools. All of the carbon and nitrogen in the grain, along with a percentage of carbon and nitrogen in the leaves and stems, is harvested and respired to the atmosphere. The remaining above-ground and all of the below-ground carbon and nitrogen are considered residue and are returned to the litter pool as such, simulating residue management practices. Variability of residue amounts in CLM-Crop enables study of the impact of different residue management practices on soil carbon.

\subsection{Input data}

\subsubsection{Climate}

Simulations required three-hourly data for temperature, wind speed, humidity, precipitation, solar radiation, and surface pressure from the National Center for Environmental Prediction (NCEP) reanalysis data for the period 1948-2004, as described by Kalnay et al. (1996). We cycled through the NCEP reanalysis data to spin up the model and reach a steady state of carbon and nitrogen in the soil (Thornton and Rosenbloom, 2005). CLM-Crop was run at a resolution of $2.8^{\circ}$ latitude by $2.8^{\circ}$ longitude.

\subsubsection{Land use}

Natural vegetation cover in CLM-Crop was represented by 14 PFTs, whose abundance was based on satellite data described by Bonan et al. (2002). Natural vegetation PFTs included needleleaf evergreen and deciduous trees, broadleaf evergreen and deciduous trees, shrubs, and grasses, all of which were divided among boreal, temperate, and tropical regions. We used data from Leff et al. (2004) to derive crop coverage maps representative of the year 1992, by separating individual crop types of maize, soybean, and wheat from the total crop area of Bonan et al. (2002). Remaining crop area not designated as maize, soybean, or wheat was attributed to an alternative PFT, called "other crop," which was modeled as a $\mathrm{C} 3$ grass. Because crop area data sets did not distinguish winter wheat from spring wheat, we included winter wheat areas in our spring wheat data. Double cropping was also included in the data sets, causing total crop area to be counted twice in some grid cells of CLM-Crop.

\subsubsection{Planting date and PHUs}

The planting date for each crop was derived from the Crop Calendar Dataset (Sacks et al., 2010). Spatial planting data for maize, soybean, and spring wheat were based on the average planting date, aggregated from $5 \mathrm{~min}$ resolution to $2.8^{\circ}$ for use in CLM-Crop. PHUs were also based on Sacks et al. (2010), calculated from the average number of HUs between the average planting and harvest dates, which were determined by regional climatology from the CRU data set (New et al., 1999) for the years 1961-1990. The Crop Calendar Dataset accounts for generalized planting dates over large regions from the dominant crop cover, using nearest neighbor extrapolation over regions where data is not available. The data set does not capture small-scale variability in planting both spatially and temporally (Sacks et al., 2010); however, as our resolution is course, we believe that this database is appropriate for this application. We did not consider double cropping or crop rotation in CLM-Crop.

\subsection{Model simulation}

An accelerated spin-up procedure (Thornton and Rosenbloom, 2005) was used to build up soil organic carbon levels in CLM-Crop, with natural vegetation only (crop areas simulated as C3 grass). Once soil carbon and nitrogen pools reached steady state, the land use was converted to include croplands. Our agriculture scenario (hereafter CROP) was established to simulate current management and fertilizer practices and represent the agricultural practices common over the United States during the last decade (www.usda.gov). We compared these results with a grassland scenario (hereafter GRASS) that included the land cover used in the spin-up (i.e., with crops simulated as C3 grass). Each scenario was run for three complete cycles of the 19482004 climate data (a total of $171 \mathrm{yr}$ ) at an hourly time step to reach a steady state. The last $57 \mathrm{yr}$ of each simulation (one cycle of 1948-2004) was included in results that show averaged data. We focused our evaluation on comparisons of CROP with observations and GRASS. In addition, we considered four case studies to evaluate the impact of residue returns and a climate-induced planting date on crop yield and GPP. 


\section{Results}

\subsection{Model performance compared with observations}

\subsection{1 $\mathrm{CO}_{2}$ fluxes}

For crops, $\mathrm{CO}_{2}$ flux data are available from two sites in the AmeriFlux network (http://public.ornl.gov/ameriflux): Bondville, IL $\left(40.01^{\circ} \mathrm{N}, 88.29^{\circ} \mathrm{W}\right)$ and a rain-fed site in Mead, NE $\left(41.18^{\circ} \mathrm{N}, 96.43^{\circ} \mathrm{W}\right)$. These sites are chosen because they contain GPP (the rate of carbon captured and stored for growth in the plant through photosynthesis), net ecosystem exchange (NEE; GPP minus the total ecosystem autotrophic and heterotrophic respiration), and LAI data for a maize-soybean rotation. Although GPP is not directly measured at Ameriflux stations, GPP is calculated in the AmeriFlux Level 4 data as the difference between ecosystem respiration and NEE. Ecosystem respiration is estimated using Reichstein et al. (2005), and NEE data are gap-filled by using the artificial neural network method (Papale and Valentini, 2003). In the absence of observations with spring wheat, we discuss only maize and soybean. Both sites were planted with maize in 2001 and with soybean in 2002. For comparison purposes, since CLM-Crop is run at a global resolution of $2.8^{\circ}$, we chose the grid cell closest to the site. In this case, the grid cell central coordinates are $40.46^{\circ} \mathrm{N}, 87.19^{\circ} \mathrm{W}$ for Bondville and $40.46^{\circ} \mathrm{N}, 95.625^{\circ} \mathrm{W}$ for Mead.

Peak monthly average GPP for maize is observed during the middle of the growth period, when LAI peaks. CROP simulates lower GPP than observations for maize during this time for the two sites; however, GPP estimates later in the growth season are comparable with measured values at Bondville and Mead (Fig. 2a, d). The annual total GPP simulated by CLM-Crop is $1197 \mathrm{~g} \mathrm{C} \mathrm{m}^{-2} \mathrm{yr}^{-1}$, which is comparable to observations of $1168 \mathrm{~g} \mathrm{C} \mathrm{m}^{-2} \mathrm{yr}^{-1}$ at Bondville. At the Mead site, the simulated GPP total of $1199 \mathrm{~g} \mathrm{C} \mathrm{m}^{-2} \mathrm{yr}^{-1}$ is lower than observed values of $1370 \mathrm{~g} \mathrm{C} \mathrm{m}^{-2} \mathrm{yr}^{-1}$. CROPsimulated maize GPP drops shortly after fertilizer application is complete, resuming again during the grain fill stage of the growth period, when nitrogen is remobilized. The drop in GPP is the result of nitrogen stress at the end of the fertilization period and loss of excess nitrogen due to a high denitrification factor. Denitrification in CLM-CN accounts for a $50 \%$ loss of unused nitrogen in the soil. The denitrification factor was intended to account for losses of nitrogen in a saturated-nitrogen environment, such as one induced by fertilizer inputs. However, since fertilizer is applied over a 20 day period, rapid loss of most of the fertilizer after the early growth phase causes a nitrogen limitation in maize during the middle growth stages. Because maize has a higher nitrogen demand than soybean and wheat, loss of unused fertilizer from denitrification results in significant nitrogen limitation for growth. During the late growth period, remobilization of nitrogen from leaves and stems allows grain access, so GPP increases (and peaks) during the organ development stage. That this is an artifact introduced by rapid denitrification in the current version of CLM is widely recognized. The nitrogen scheme in the model is undergoing a thorough evaluation and reformulation (Tang et al., 2013). The new nitrogen scheme is expected to circumvent the problem with the current formulation, making the nitrogen availability to maize more uniform and the GPP calculations closer to observations during the early phase of the crop growth cycle. NEE (Fig. 2b, e) shows characteristics similar to GPP. Although the timing is not always synchronized with observations as a result of our use of fixed values for planting and growth periods, the model does capture the general trend of NEE during the growth period for both the Bondville and Mead AmeriFlux sites, demonstrating the model's ability to simulate ecosystem respiration. The total annual NEE is underestimated by CLMCrop; at Bondville, simulated NEE was $-322 \mathrm{~g} \mathrm{C} \mathrm{m}^{-2} \mathrm{yr}^{-1}$ compared to $-405 \mathrm{~g} \mathrm{C} \mathrm{m}^{-2} \mathrm{yr}^{-1}$ observed. At Mead, total NEE in CLM-Crop was $-314 \mathrm{~g} \mathrm{C} \mathrm{m}^{-2} \mathrm{yr}^{-1}$, but measured at $-545 \mathrm{~g} \mathrm{C} \mathrm{m}^{-2} \mathrm{yr}^{-1}$.

CROP-simulated GPP for soybean agrees well with observations at Mead, but it increases early and is too high at Bondville (Fig. 2g, j). The earlier planting date in the model causes GPP at the Bondville site to be offset by more than one month from observations, while the longer growth period at Bondville causes modeled GPP to be higher than the measured value. The annual total simulated GPP at Bondville for soybean is $1055 \mathrm{~g} \mathrm{C} \mathrm{m}^{-2} \mathrm{yr}^{-1}$ versus observations of $773 \mathrm{~g} \mathrm{C} \mathrm{m}^{-2} \mathrm{yr}^{-1}$. Growth period length is well estimated at the Mead site, and GPP values match observations, although total annual GPP is overestimated at $904 \mathrm{~g} \mathrm{C} \mathrm{m}^{-2} \mathrm{yr}^{-1}$ where observations indicate $798 \mathrm{~g} \mathrm{C} \mathrm{m}^{-2} \mathrm{yr}^{-1}$. For soybean, simulated GPP is higher than the measured value as a result of cropping sequence. The lower soybean biomass at the end of the growth period decreases the amount of decomposition, and thus nitrogen immobilization, the year following soybean planting. However, in a maize-soybean rotation, maize residue from the previous year's crop immobilizes more soil nitrogen for decomposition, leaving less available for soybean growth. With no rotation in CLM-Crop and no simulation of this phenomenon in the model, more nitrogen becomes available for growth. Simulated NEE values for soybean (Fig. 2h, k) are similar to the corresponding GPP values, however, simulated NEE of $-228 \mathrm{~g} \mathrm{C} \mathrm{m}^{-2} \mathrm{yr}^{-1}$ is overestimated compared to observations of $-25 \mathrm{~g} \mathrm{C} \mathrm{m}^{-2} \mathrm{yr}^{-1}$. CROP NEE is slightly greater than observations at the Bondville site during the growth season because of higher GPP, with annual total values of $-257 \mathrm{~g} \mathrm{C} \mathrm{m}^{-2} \mathrm{yr}^{-1}$ versus observations of $-142 \mathrm{~g} \mathrm{C} \mathrm{m}^{-2} \mathrm{yr}^{-1}$. To introduce crop rotation into the model requires a data set on crop rotation at the grid scale and a model capability to simulate changes in land use, which currently are not available. As these improvements become available, we expect to introduce crop rotation into the next model update. 

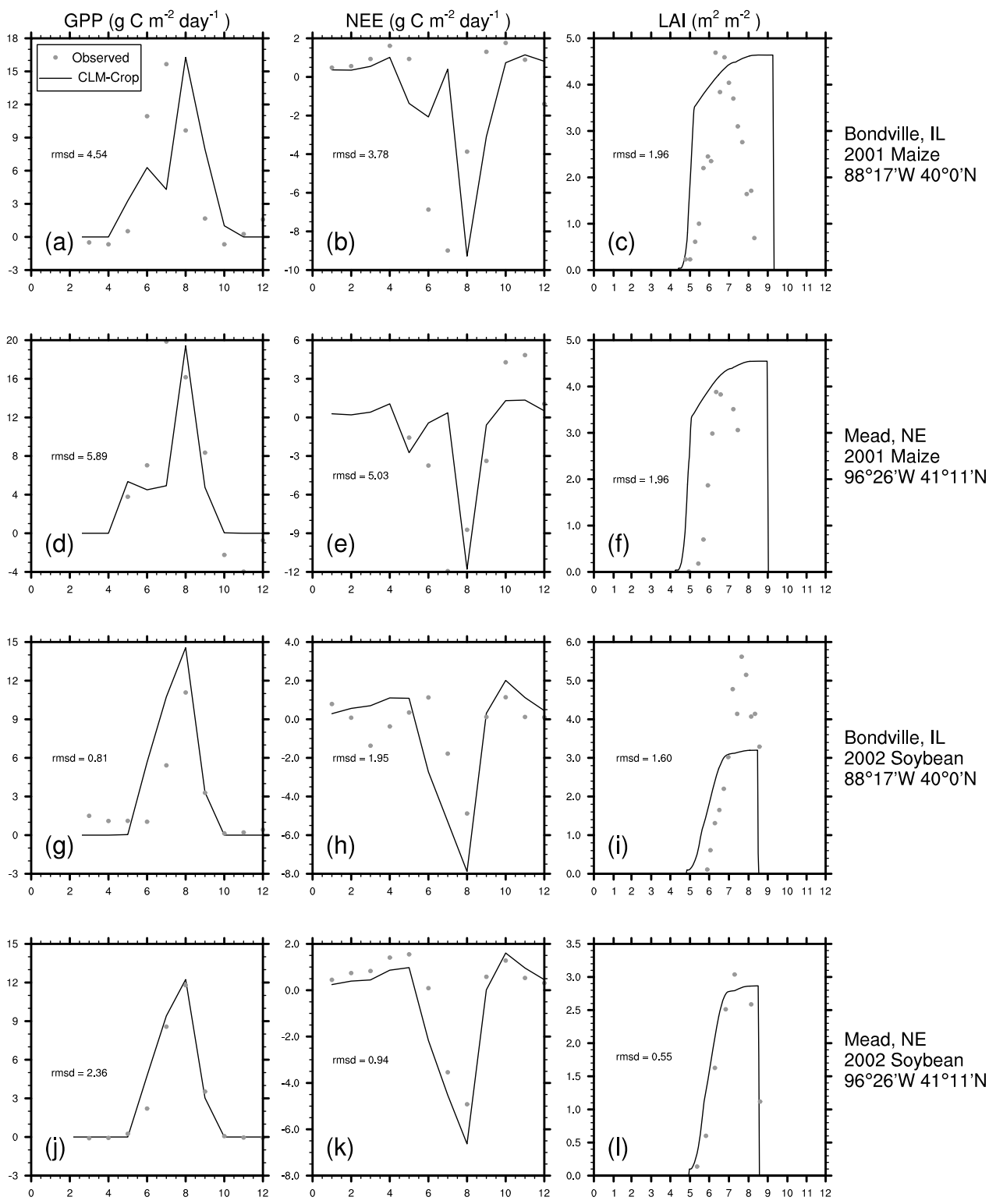

Fig. 2. Simulated (lines) and observed (circles) monthly averaged gross primary productivity (GPP; $\mathrm{g} \mathrm{C} \mathrm{m}^{-2}$ day $\left.^{-1}\right)$, net ecosystem exchange

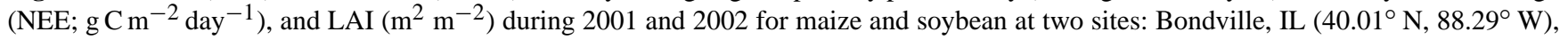
and Mead, NE $\left(41.18^{\circ} \mathrm{N}, 96.43^{\circ} \mathrm{W}\right)$.

Global average GPP from 2000 through 2004, simulated by CROP, shows improvement versus GRASS in comparison with MODIS satellite data (Zhao et al., 2005), as shown in Fig. 3. In regions with high crop density, GPP is lower in CROP than in GRASS, particularly in the US Midwest, western Brazil, Europe, the United Kingdom, and Asia. Overall, crop representation improved the root-mean-squared error (RMSE) by a small amount, $3 \%$; locally, however, in regions where croplands are dominant, RMSE shows more significant improvement (Table 2). For example, in the United States, France, and Mexico, the RMSE was about $15 \%$ lower for CROP than for GRASS. In South Africa, Greece, the Netherlands, and Turkey, the RMSE for CROP was more than $10 \%$ lower, while in the United Kingdom, the RMSE for $\mathrm{CROP}$ was $8 \%$ lower.

\subsubsection{Leaf area index}

Simulated peak LAI for maize and soybean (Fig. 2c, f, i, l) is generally consistent with observations at both the Mead and Bondville sites. However, because LAI decline is not simulated in the model, LAI values are higher than observations late in the growth period. This also allows the GPP to remain 

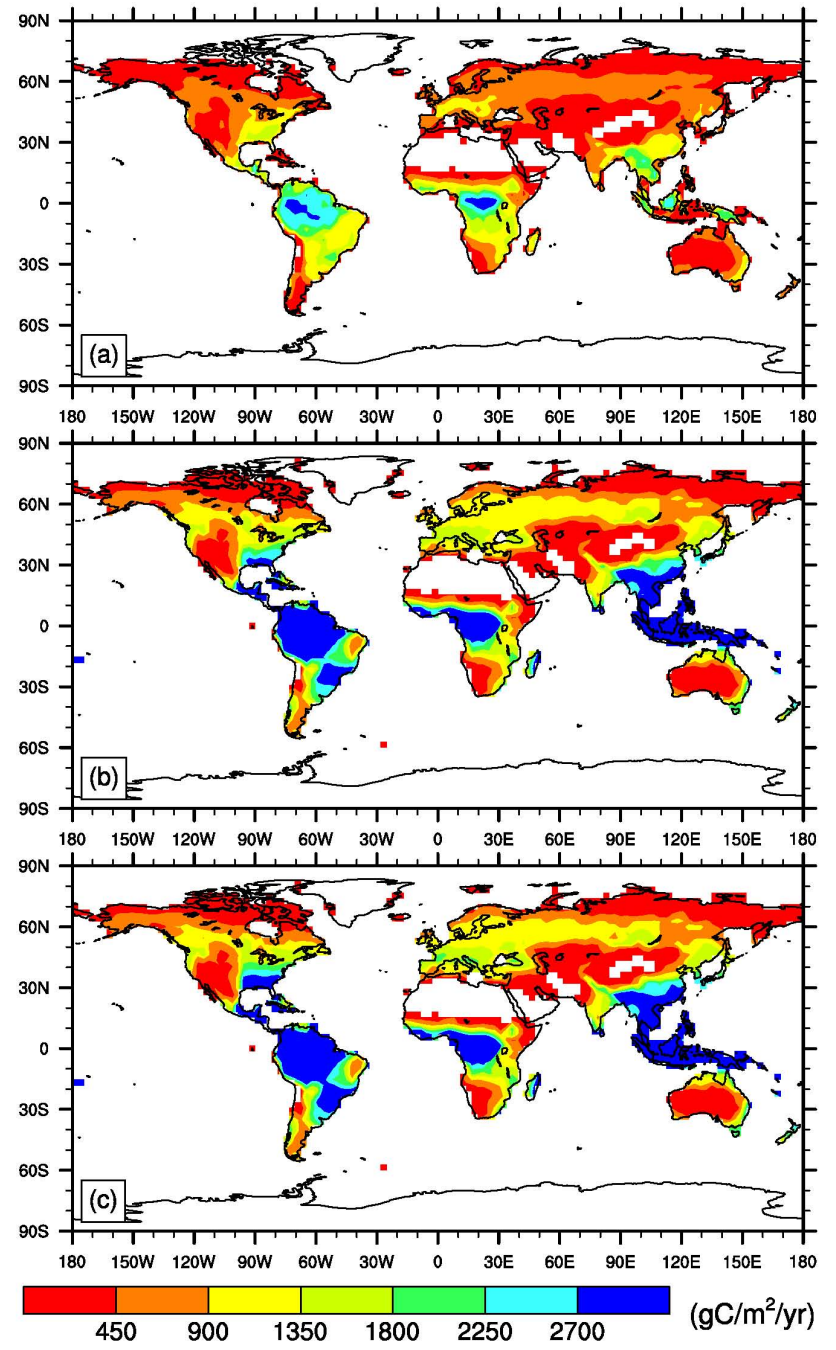

Fig. 3. Average GPP $\left(\mathrm{g} \mathrm{C} \mathrm{m}^{-2} \mathrm{yr}^{-1}\right)$ for the years 2000-2004, derived from (a) MODIS data (Zhao et al., 2005), (b) CROP, and (c) GRASS.

high in the late growth stages, producing higher yields than observed, because more carbon is assimilated in the simulation.

The LAI in the model is based on the amount of carbon in the leaves and a constant specific leaf area (SLA; the ratio of leaf area to dry leaf weight) for each crop type; however, observations show that SLA actually varies throughout the growth season (Tardieu et al., 1999) and with nitrogen fertilizer application methods (Amanullah et al., 2007), causing discrepancies between observed and model-simulated LAI. To allow varying SLA with growth period would be difficult, because this requires detailed knowledge of how SLA responds to climate for each crop during each growth phase. For maize, LAI is overestimated, particularly in the early growing season, despite having less leaf carbon throughout the growth period (Fig. 4a). Soybean LAI values for
Table 2. Root-mean-squared error of GPP for selected regions from CROP and GRASS simulations, as compared with MODIS satellite data of Zhao et al. (2005).

\begin{tabular}{llll}
\hline Country & CROP & GRASS & Percent Change \\
\hline United States & 510.86 & 581.77 & -12.19 \\
France & 625.62 & 751.16 & -16.71 \\
Mexico & 712.22 & 855.15 & -16.71 \\
Spain & 475.86 & 505.03 & -5.78 \\
Italy & 809.42 & 861.61 & -6.05 \\
Germany & 359.30 & 381.11 & -5.72 \\
South Africa & 240.14 & 266.87 & -10.01 \\
Greece & 727.64 & 806.89 & -9.82 \\
Netherlands & 422.54 & 478.28 & -11.65 \\
Portugal & 801.06 & 845.56 & -5.20 \\
Turkey & 618.34 & 684.91 & -9.71 \\
United Kingdom & 431.07 & 468.62 & -8.01 \\
\hline
\end{tabular}

the Mead site are comparable with observations. For the Bondville site, soybean LAI values are underestimated despite the high GPP; however, the similarity of simulated leaf carbon to observations for this site (Fig. 4d) demonstrates the importance of variable SLA.

\subsubsection{Plant carbon}

The total carbon distributed in the leaves, stems, and organs of maize and soybean for the Bondville site is shown in Fig. 4. Leaf carbon in maize is underestimated by the model, because nitrogen stress constrains growth in the early to middle growth phase, in contrast to field observations. Carbon in the stem is comparable with observations during the emergence stage; however, organ carbon is underestimated by a factor of two. Because organ development relies heavily on retranslocated nitrogen from leaves and stems and because maize was limited by nitrogen stress earlier in the growth season, the lower organ carbon than observations is not surprising.

Leaf carbon for soybean is overestimated during most of the growth period because of early planting; however, peak leaf carbon agrees with observations. High simulated GPP for soybean caused stem and organ carbon to be overestimated by the model, as compared with field measurements.

Carbon levels for the Mead site were not separated into crop components, but total carbon in the above-ground biomass was reported. Our simulated carbon values for maize and soybean at that rain-fed site are shown in Fig. 5. Peak estimates of above-ground carbon for maize in the model are similar to observations but are offset because of nitrogen limitation in the early to middle growth stages. When nitrogen is remobilized for grain development, total carbon in the plant increases until late in the growth season, because the lack of LAI decline causes the peak carbon to occur later in the model than in field measurements. Total 

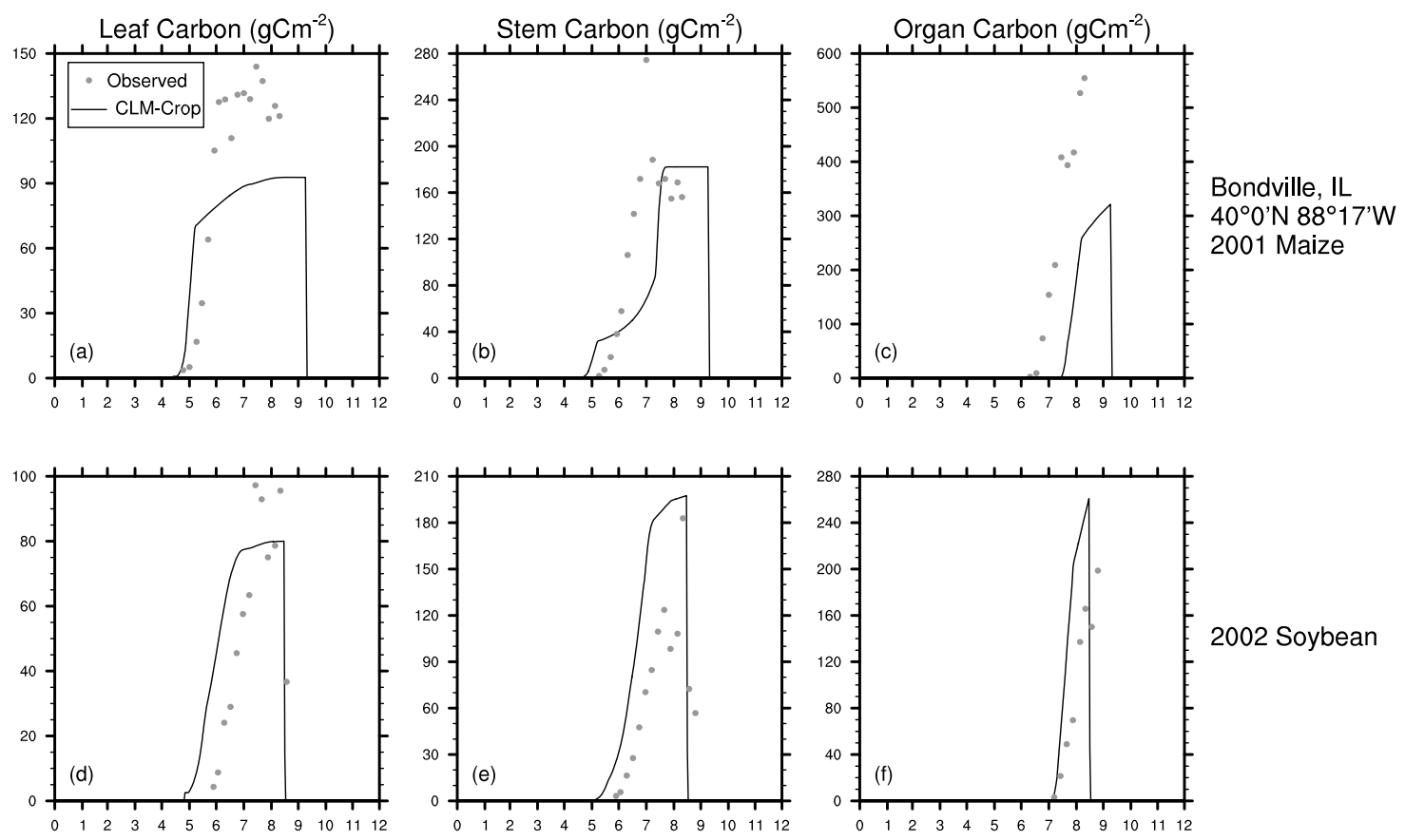

2002 Soybean

Fig. 4. Simulated (lines) and observed (circles) leaf, stem, and organ carbon $\left(\mathrm{g} \mathrm{C} \mathrm{m}^{-2}\right)$ during 2001 and 2002 for maize and soybean at Bondville, IL.

soybean above-ground carbon is overestimated by the model. Although carbon is modeled well in the early growth season, total plant carbon peaks at higher values versus observations in the grain fill stage. The early curve and timing of the carbon growth are simulated well for soybean, and the peak carbon is simulated well for maize in CROP.

\subsubsection{Yields}

The average yields estimated by CROP for the last $57 \mathrm{yr}$ of the simulation are shown in Fig. 6 for maize, wheat, and soybean. Direct comparison of yields with observations is difficult, because CROP does not include improved technology and management practices (such as irrigation) that affect yield; therefore, our results might differ significantly from observations in certain regions and do not include the large advances in yield seen over the last several decades. The results presented here should be considered a baseline for calculating crop yields in the absence of these additional interventions. These results provide a template for assessing the impacts of management changes in the future as climate models become more capable of handling socioeconomic and external interventions in land management and land use.

Average yearly US crop yields (Fig. 7) for the last $57 \mathrm{yr}$ of the simulation are $116 \mathrm{bu} \mathrm{acre}^{-1}$ for maize, $66 \mathrm{bu}$ acre ${ }^{-1}$ for soybean, and $47 \mathrm{bu} \mathrm{acre}^{-1}$ for wheat. Yield variability is caused mainly by variations in climate, particularly precipitation. In general, higher rainfall amounts and more frequent rainfall events allow the model to simulate higher yields. CROP-simulated average yield for maize is lower than US Department of Agriculture (USDA) statistics (www.usda.gov), with current production of nearly $165 \mathrm{bu} \mathrm{acre}^{-1}$ due to advances in management and hybrid technology. Wheat yields in CROP are very similar to current reports by the USDA (www.usda.gov), at 44 bu acre $^{-1}$; however, soybean yields are overestimated compared to the USDA's 45 bu acre ${ }^{-1}$. Since soybean and spring wheat in the model do not experience as much nitrogen or water stress as maize crops, soybean and wheat do not experience a GPP drop during the early to middle growth phase. Spring wheat yield averages in Figs. $6 \mathrm{~b}$ and 7 include all wheat types in each region, so we focus our discussion on the northern United States and some western states, where spring wheat is typically grown.

Simulated US maize yields (Fig. 6a) are comparable with observations in the central Midwest, where differences between simulated yield and those reported by Monfreda et al. (2008) are generally less than $20 \%$. Yields in the western states have the highest percent difference, up to $80 \%$ (due to drier conditions), a result of no irrigation in the model and the loss of fertilizer due to denitrification. Observations from the Mead AmeriFlux site demonstrated the importance of irrigation for maize yields, a phenomenon also seen in other crop models (Bondeau et al., 2007).

Soybean yields simulated for the central states (Fig. 6c) are generally higher than observations, by a factor of two in some regions. The absence in CLM-Crop of the LAI decline 


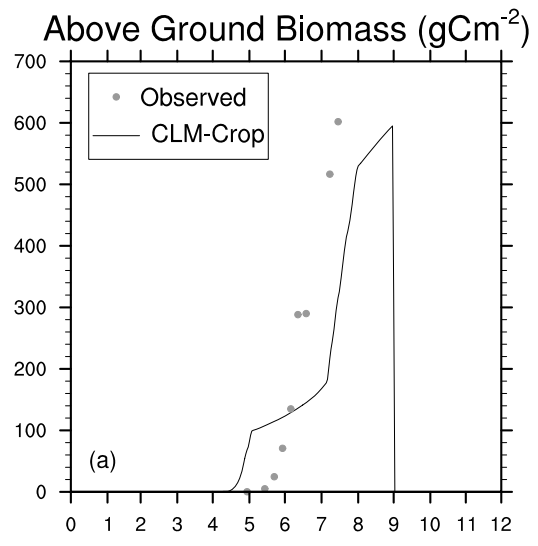

Mead, NE $41^{\circ} 11^{\prime} \mathrm{N} 96^{\circ} 26^{\prime} \mathrm{W}$ 2001 Maize

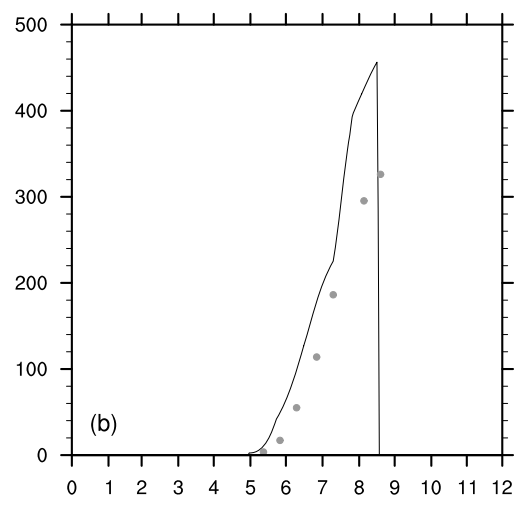

2002 Soybean

Fig. 5. Simulated (lines) and observed (circles) total plant carbon (g $\mathrm{C} \mathrm{m}^{-2}$ ) during 2001 and 2002 for maize and soybean at Mead, NE.

during grain fill can cause higher LAI in the late growth season, which leads to higher GPP. Yields are greatest in Illinois, Indiana, and Michigan, where crops are grown intensely. In the western states, yields are lower than observations, like the maize yields.

Spring wheat yields (Fig. 6b) are also overestimated in the northern states where typical values are less than $40 \mathrm{bu}$ acre $^{-1}$, with simulated yields above 70 bu acre $^{-1}$. The model does capture higher yields in the northwestern states that can exceed 60 bu acre $^{-1}$. Our comparison with the data of Monfreda et al. (2008) is limited, because they did not distinguish winter and spring wheat.

Global yield spreads compared with those of Monfreda et al. (2008) are shown in Fig. 8. In general, CROP median yields are higher than observed yields for all crops, but yields vary regionally, mostly because the baseline growth model in CLM-Crop is representative of North America. Globally, the full range of CROP yields for maize and wheat falls within the range of observed yields, although the spread of yields is quite large. Regionally this result is not always true. Yield has a large dependence on fertilizer rates, both in the model and in the field. Fertilizer statistics from the Food and Agriculture Organization (www.fao.org) reveal a large range in

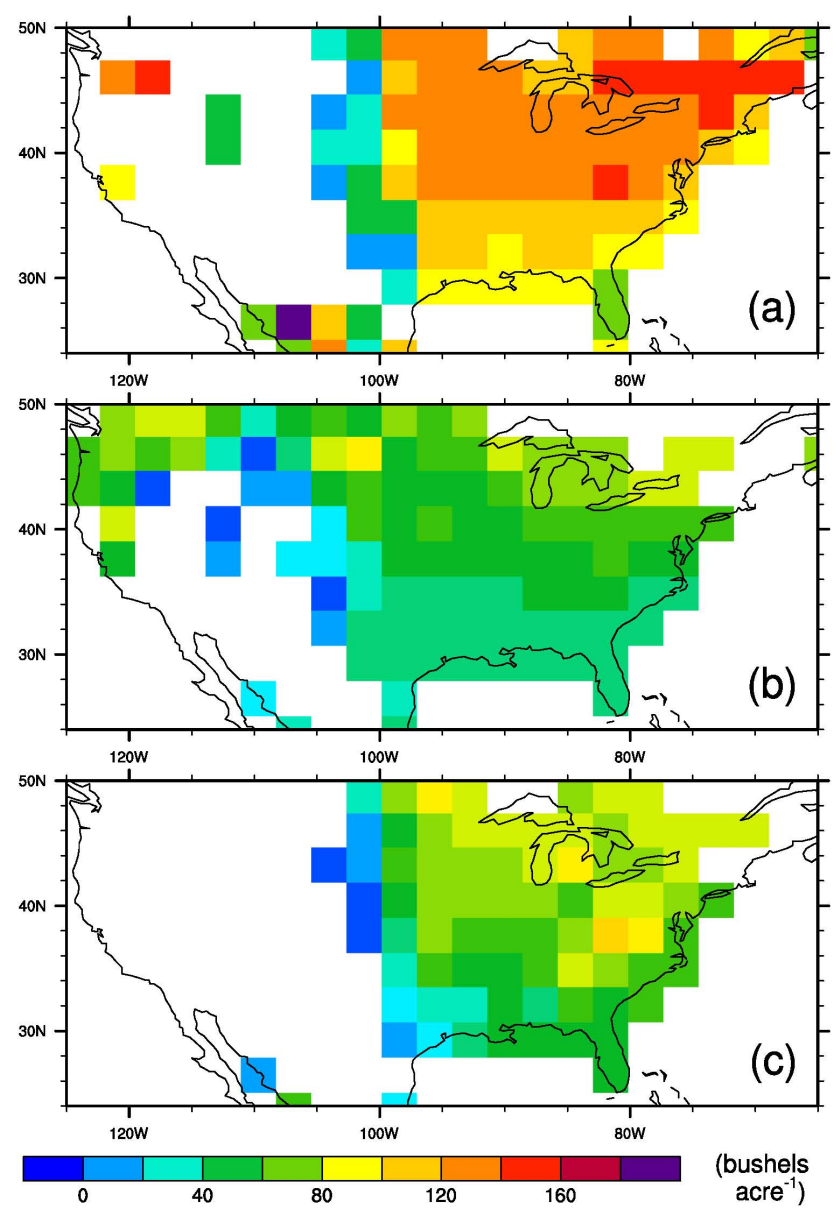

Fig. 6. Simulated crop yields (bu acre ${ }^{-1}$ ) for (a) maize, (b) wheat, and (c) soybean.

fertilizer use, further increasing the difficulty of comparing CROP-simulated yields with observations.

Nevertheless, CROP-simulated median yields for most regions fall within the range of observed yields (i.e., maize in the United States, Argentina, and China; wheat globally and in the United States, China, and Italy; and soybean in Brazil). Both soybean and spring wheat are overestimated in the United States; however, the range of maize and spring wheat yields simulated by CROP falls within the observed range of yields. Simulated soybean yields have a greater range than observations, demonstrating higher simulated variability in soybean yield across the United States, and $50 \%$ of the soybean yields from CROP are higher than the observed yields (Fig. 8). In Argentina, the range of CROP-simulated maize production falls within the range of observations; in South Africa, the range of simulated maize yields has a larger spread than the observed value, and the median is much higher than the observed median yield.

Considering crop rotation in the model might improve the yields in CLM, because soybean, as a legume, has the ability to fix more nitrogen than do other crop types, thus 


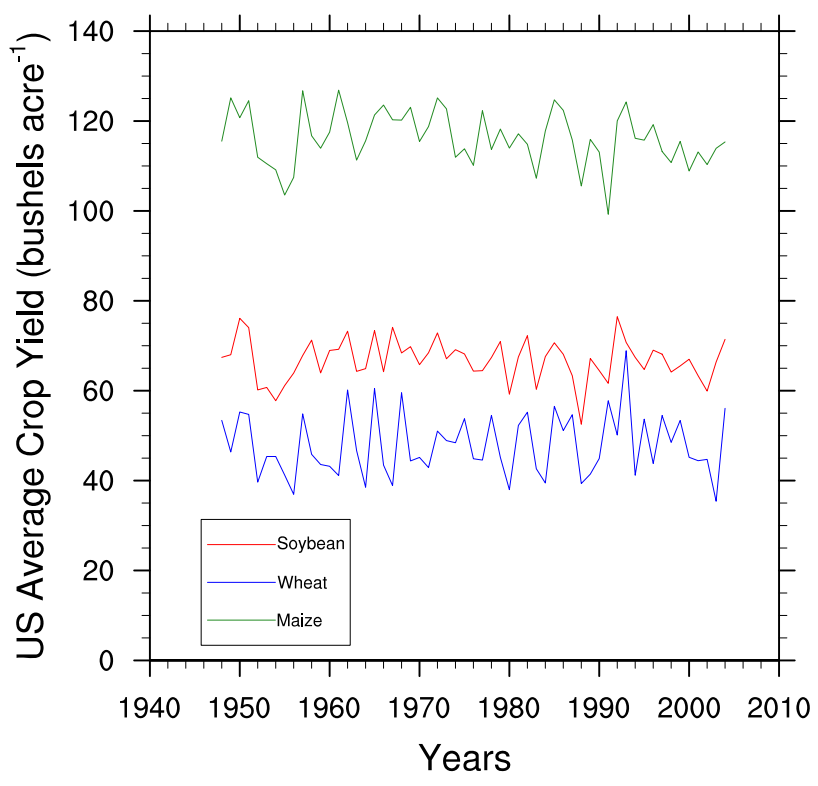

Fig. 7. Simulated average US crop yields $\left(b u\right.$ acre $\left.{ }^{-1}\right)$ for maize, wheat, and soybean.

improving performance when rotated with maize or wheat over long-term cultivation. In addition, having fixed fertilizer rates in CLM-Crop will result in higher crop production (for example, in Brazil, where farmers typically use little if any fertilizer). CROP does not perform well in boreal regions such as Canada (Fig. 8) and Russia (not shown). CROP overestimates yields in these regions for all crop types, although comparisons are difficult, because fertilizer rates in these countries are much lower than those in the model. In Argentina, wheat and soybean are overestimated, and soybean simulations have a larger yield range than observed. In China, CROP underestimates maize yield, with the median falling just inside the $25 \%$ percentile of observed range as a result of excessive fertilizer use in this region. However, soybean is grown only in small quantities in China, with smaller fertilizer rates than are used in CROP, so simulated yields tend to be overestimated. In Italy, maize is greatly underestimated by CROP, but the course grid cell size of CROP allows only a few pixels to represent Italy in the model and makes comparison with observations difficult. CROP overestimates of Venezuelan yields are also the result of higher fertilizer in the model than is typically used in cultivation.

\subsection{Climate influence on crop yields}

\subsubsection{Temperature}

Temperature has a strong negative correlation coefficient with yield for all crop types (Fig. 9), consistent with other measurements (Lobell and Field, 2007) and model simulations (Osborne et al., 2009). The slope of the regression between the standardized anomalies of yield and temperature (not shown) is -0.26 for maize, -0.27 for spring wheat, and -0.63 for soybean. In general, the negative correlation between temperature and yield is the result of shorter growth periods caused by warm temperatures. Because plants are accumulating PHUs faster during higher-temperature episodes, the total length of the growth period and thus the time for development are shorter, lowering the potential for grain development. The latitudinally averaged maximum and minimum temperatures during the growth period are shown to the right of each graph in Fig. 9. For soybean, the negative correlation coefficient is strongest because of a later planting date reflected by a warmer growth period, as demonstrated by the large latitudinal bands with average maximum temperature exceeding $30^{\circ} \mathrm{C}$. Maize and wheat have a weaker correlation, and in some cases the correlation coefficient is positive. In most of the grid cells with the positive temperature and yield correlation coefficients, minimum and average daily temperatures were not sufficient to allow growth, causing the season to terminate prematurely. Therefore, yield suffered. Comparison with the minimum temperature during the growth season shows that in these latitudes, the minimum temperature was below the base temperature, which significantly slowed development and in some cases stopped it completely.

\subsubsection{Precipitation}

The correlation coefficient between precipitation and yields is strongly positive (Fig. 10). The slope of the regression between the standardized anomalies of yield and precipitation (not shown) is 0.19 for maize, 0.41 for spring wheat, and 0.38 for soybean. The positive correlation coefficient is strongest in the western United States, because the rainfall during the growth period was smallest in that region (Fig. 10). Crops in the western United States are usually irrigated because of the lower rainfall amounts; we anticipate that including irrigation in a future version of the model will improve the variability of yield for areas that rely on irrigation. As the average precipitation during the growth period across the longitude increases (shown below each graph in Fig. 10), the strength of the correlation weakens and in some cases becomes negative (i.e., for maize). We note that the variability and timing of rainfall (i.e., extreme rainfall events) have a strong influence on yield variability (Rosenzweig et al., 2002). 

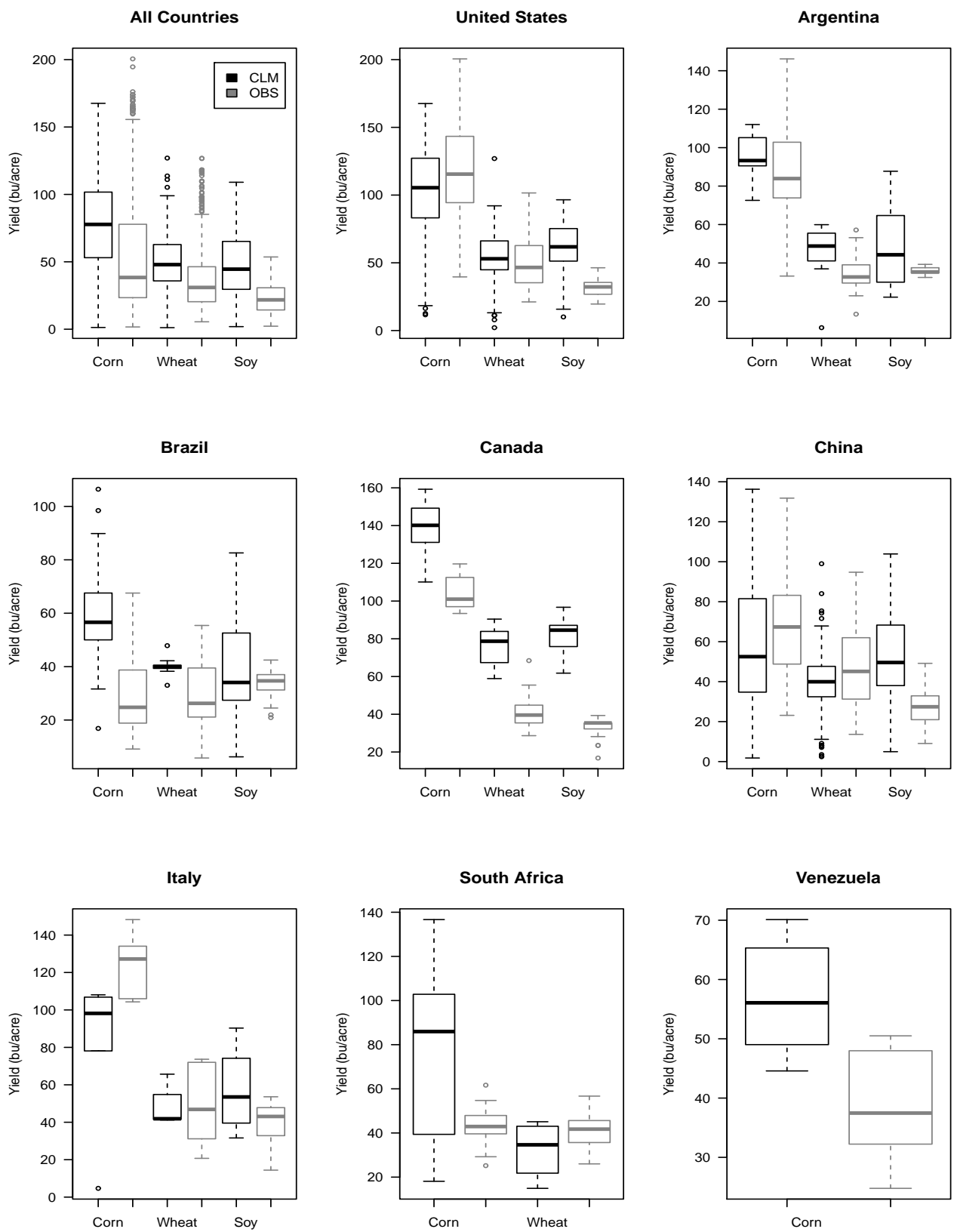

Fig. 8. CLM-Crop-simulated (black) and observed (gray; data from Monfreda et al., 2008) yields (bu acre ${ }^{-1}$ ) for maize, wheat, and soybean of selected regions.

\section{Case studies}

\subsection{Sensitivity of yield and GPP to residue management}

To evaluate the impact of residue management on yield and productivity, we tested two alternative residue returns (see Table 3): a high residue return of $70 \%$ (HIGHRES) and a low residue return of $10 \%$ (LOWRES). The HIGHRES scenario would be typical of sustainable agriculture practices, minimizing the carbon removed from the field for alternative use and returning residue to the soil. The LOWRES scenario represents a society with increased demand of biofuel from agriculture residues. The amount of residue returned to the litter pools affects decomposition and soil nutrients in the below-ground biogeochemistry, which will influence future growth periods through nutrient availability. This should not be confused with tillage practices, which are not represented in the model.

Increasing the amount of residue returned to the litter pool after harvest has a positive influence on crop yield and GPP, globally. Likewise, decreasing the residue causes a decrease 
Table 3. Parameter values for the baseline CLM-Crop simulation and the case studies.

\begin{tabular}{lllll}
\hline Type of Change & Scenario & Maize & Spring Wheat & Soybean \\
\hline $\begin{array}{l}\text { Residue Management ( } \% \text { non- } \\
\text { grain residue returned to litter } \\
\text { pool) }\end{array}$ & $\mathrm{CROP}$ & $30 \%$ & $30 \%$ & $40 \%$ \\
\cline { 2 - 5 } & & & & \\
\cline { 2 - 5 } & HIGHRES & $70 \%$ & $70 \%$ & $70 \%$ \\
\cline { 2 - 5 } & LOWRES & $10 \%$ & $10 \%$ & $10 \%$ \\
\hline $\begin{array}{l}\text { Planting Date (10 day running } \\
\text { average temperature threshold } \\
\text { for planting) }\end{array}$ & $\mathrm{CROP}$ & $\mathrm{NA}-$ fixed & $\mathrm{NA}-$ fixed & $\mathrm{NA}-$ fixed \\
\cline { 2 - 5 } & HighPTEMP & $22^{\circ} \mathrm{C}$ & $21{ }^{\circ} \mathrm{C}$ & $17^{\circ} \mathrm{C}$ \\
\cline { 2 - 5 } & LowPTEMP & $12{ }^{\circ} \mathrm{C}$ & $11^{\circ} \mathrm{C}$ & $7{ }^{\circ} \mathrm{C}$ \\
\hline
\end{tabular}
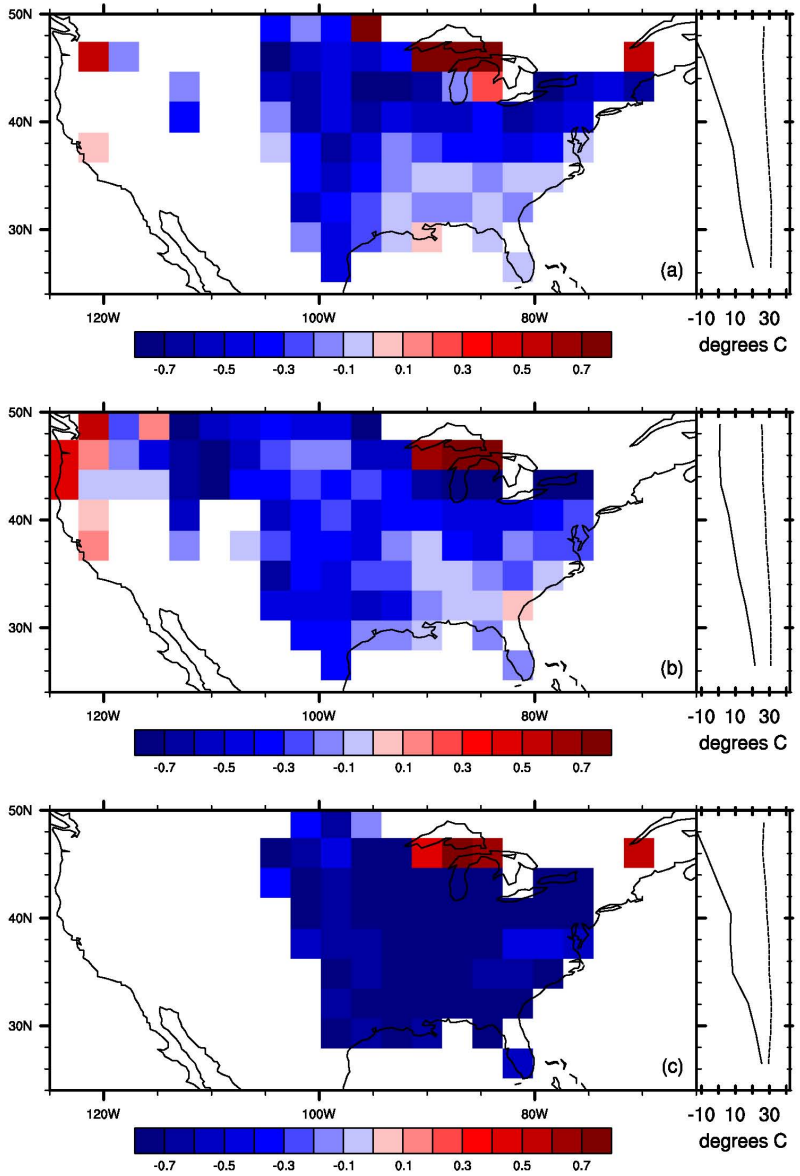

Fig. 9. Correlation coefficient between temperature and yield for (a) maize, (b) spring wheat, and (c) soybean. The right half of each panel shows the latitudinal maximum and minimum temperatures $\left({ }^{\circ} \mathrm{C}\right)$ during the growth period for each crop. in yield and GPP. Globally, for HIGHRES, yield increased by 9,8 , and $5 \%$ for maize, spring wheat, and soybean, respectively, compared to CROP. GPP likewise increased by 7 , 10 , and $4 \%$ for maize, spring wheat, and soybean, respectively. Figure 11 shows the percent change in yield and GPP for all three crop types over the United States, although the Midwest Corn Belt has a larger increase in yield and GPP for maize and spring wheat than does the western United States. Drier conditions in the West could be responsible through a slowing of decomposition; incorporation of irrigation could improve results. For LOWRES, global yields and GPP declined by $4 \%$ for maize and wheat and $7 \%$ for soybean compared to CROP. The percent change is higher in the US Midwest (Fig. 12), where farming is most concentrated. These simulations indicate that below-ground processes do have a strong influence on above-ground processes, particularly related to the turnover of carbon and nitrogen availability. Results also demonstrate that high biofuel demands leading to removal of crop residue for fuel use may result in a decline in crop productivity and degrade soil fertility over time. We note, however, that the nitrogen deficiency in the model may exaggerate the results, especially for the low residue simulation where lack of nutrients affects future soil fertility.

\subsection{Impact of variable planting date on yield and GPP}

Because planting date is usually determined by farmers' choice, taking into account temperature, precipitation, and other conditions favorable for growth, we allowed the model to determine a planting date adapted to climate conditions for the current year. In the Agro-IBIS model, planting date is determined by 10 day running means of the average daily temperature and the minimum daily temperature. In this case study, we adopted the Agro-IBIS approach to allow the model to calculate a planting date by using the same methods, but bounded by the earliest and latest planting dates as reported by the Crop Calendar Dataset (Sacks et al., 2010). If the earliest and latest planting dates were unknown, 


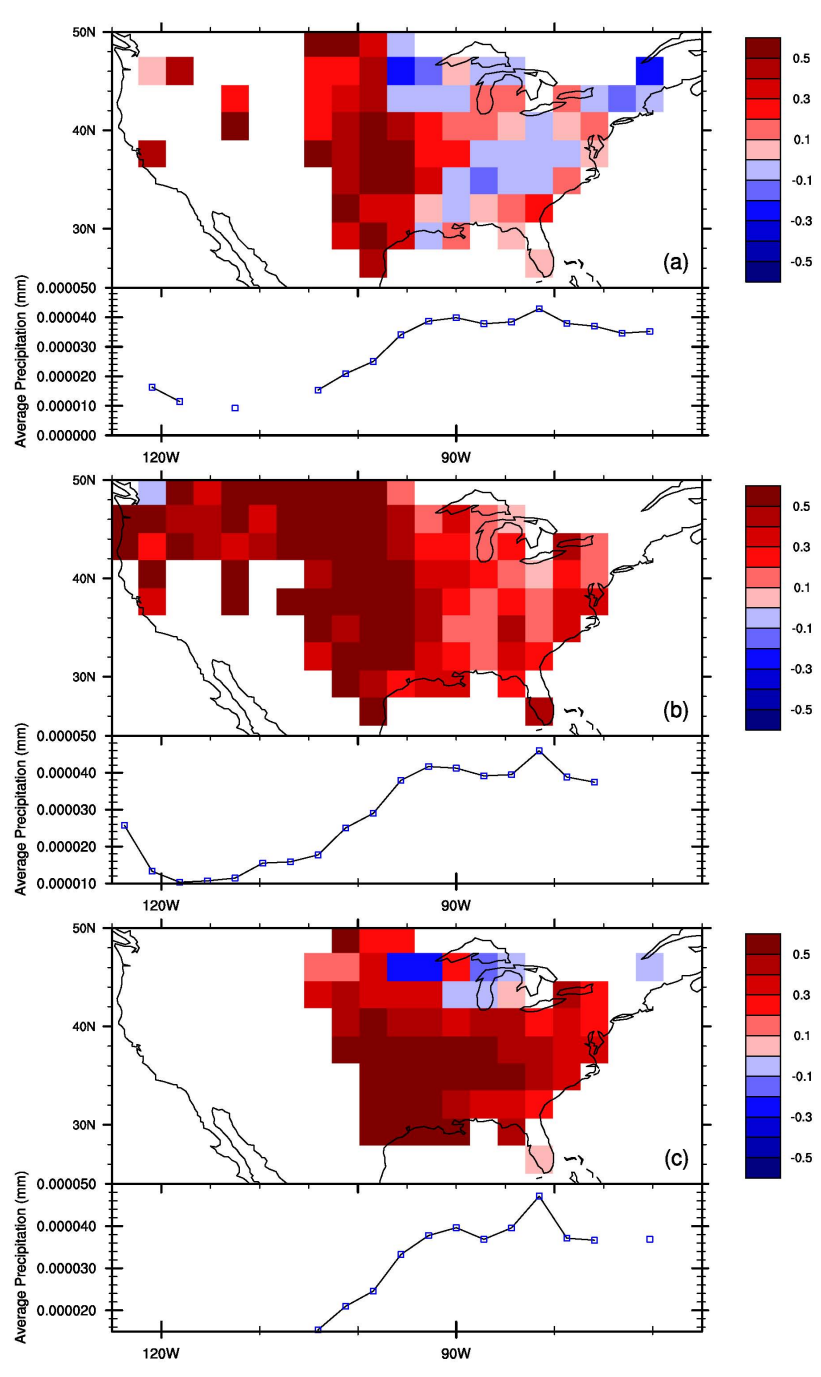

Fig. 10. Correlation coefficient between precipitation and yield for (a) maize, (b) spring wheat, and (c) soybean. The bottom half of each panel shows the longitudinal average precipitation $(\mathrm{mm})$ during the growth period for each crop.

then planting date was assumed to be fixed. This allows the model to be applied more appropriately at global scales. We performed two simulations; the first uses the same temperature thresholds as the Agro-IBIS model (LowPTEMP, Table 3), and the second uses an alternative warmer 10 day average temperature threshold (HighPTEMP, Table 3). We report changes in grid cells that were subject to the new planting dates and do not include the unchanged grid cells in our analysis. Comparisons are made against the CROP scenario.

In the LowPTEMP simulation, average planting dates for all crop types were earlier than the fixed planting dates in CROP. Maize was planted an average of 23 days earlier, wheat 5 days earlier, and soybean over 28 days earlier. Globally, however, harvest dates did not reflect the early planting; maize and wheat harvest were only 15 days and nearly
10 days earlier, respectively, than in CROP. Except for soybean, the harvest dates demonstrate that even though the planting date was considerably earlier, the overall result was a longer growth period. Separating the Northern and Southern Hemispheres ( $\mathrm{NH}$ and $\mathrm{SH}$ ) revealed a significant difference in responses. In the $\mathrm{SH}$, planting dates were significantly earlier on average than in the $\mathrm{NH}$; for maize, planting in the $\mathrm{NH}$ was on average 18 days earlier, whereas in the SH planting was nearly 25 days earlier. However, harvest was 14 days earlier in the $\mathrm{NH}$ and 17 days earlier in the $\mathrm{SH}$. In the $\mathrm{NH}$, yield increased slightly (less than $1 \%$ ), but in the SH yield decreased by $11 \%$. However, for soybean, planting date was 23 (33) days earlier and harvest was 22 (34) days earlier in the $\mathrm{NH}(\mathrm{SH})$; resulting yields were increased slightly for both hemispheres. We expect the largest change in the $\mathrm{SH}$, because the planting temperature thresholds are based on NH planting practices.

In the United States, maize and soybean were both planted early; however, the impact on yield and GPP were opposite - maize yields and GPP decreased, and soybean yields and GPP increased (Fig. 13). We also found that early planting resulted in a lower LAI for maize but a higher LAI for soybean. Small LAI slows the rate of carbon assimilation, which impedes growth and productivity; we conclude that shorter day length results in less intercepted light for photosynthesis and therefore growth. To understand soybean response, we considered a soybean fixation scheme that allows soybean to fix nitrogen in the absence of sufficient nutrients for growth. We found that in all cases, nitrogen fixation increased when soybean was planted early and decreased when soybean was planted late. We have already shown that nitrogen limitation occurs after the fertilization period (Sect. 3.1.1); therefore, these results demonstrate that early planting leads to a nitrogen deficiency for crops. Because soybean is able to overcome nitrogen limitation through additional fixation, soybean growth was not slowed in later growth stages as was maize. Wheat does not experience much sensitivity to planting date; although this scenario resulted in a later planting for wheat, changes in yield and GPP were generally less than a few percent. Overall, later planting resulted in higher yields, similarly to the maize response, indicating nitrogen stress.

HighPTEMP also resulted in earlier planting dates globally for maize and soybean than in CROP: 16 days for soybean and 2 days for maize. Wheat was planted 4 days later. Harvest dates were also earlier for wheat (2 days) and soybean (about 31 days); maize was harvested 4 days later. The resulting yields decreased by about $1 \%$ for maize and soybean, respectively, and increased by $7 \%$ for wheat. Again, significant differences existed between the $\mathrm{NH}$ and $\mathrm{SH}$ for all crop types. Planting dates were 2 days earlier for maize in both hemispheres. Wheat was planted 8 days later in the $\mathrm{NH}$ but 24 days earlier in the $\mathrm{SH}$, and soybean was planted 5 (27) days earlier in the $\mathrm{NH}(\mathrm{SH})$. Maize yields increased in the $\mathrm{NH}$ but decreased in the $\mathrm{SH}$, though soybean experienced a lower yield in the $\mathrm{NH}$ and an increase in the SH. Wheat 


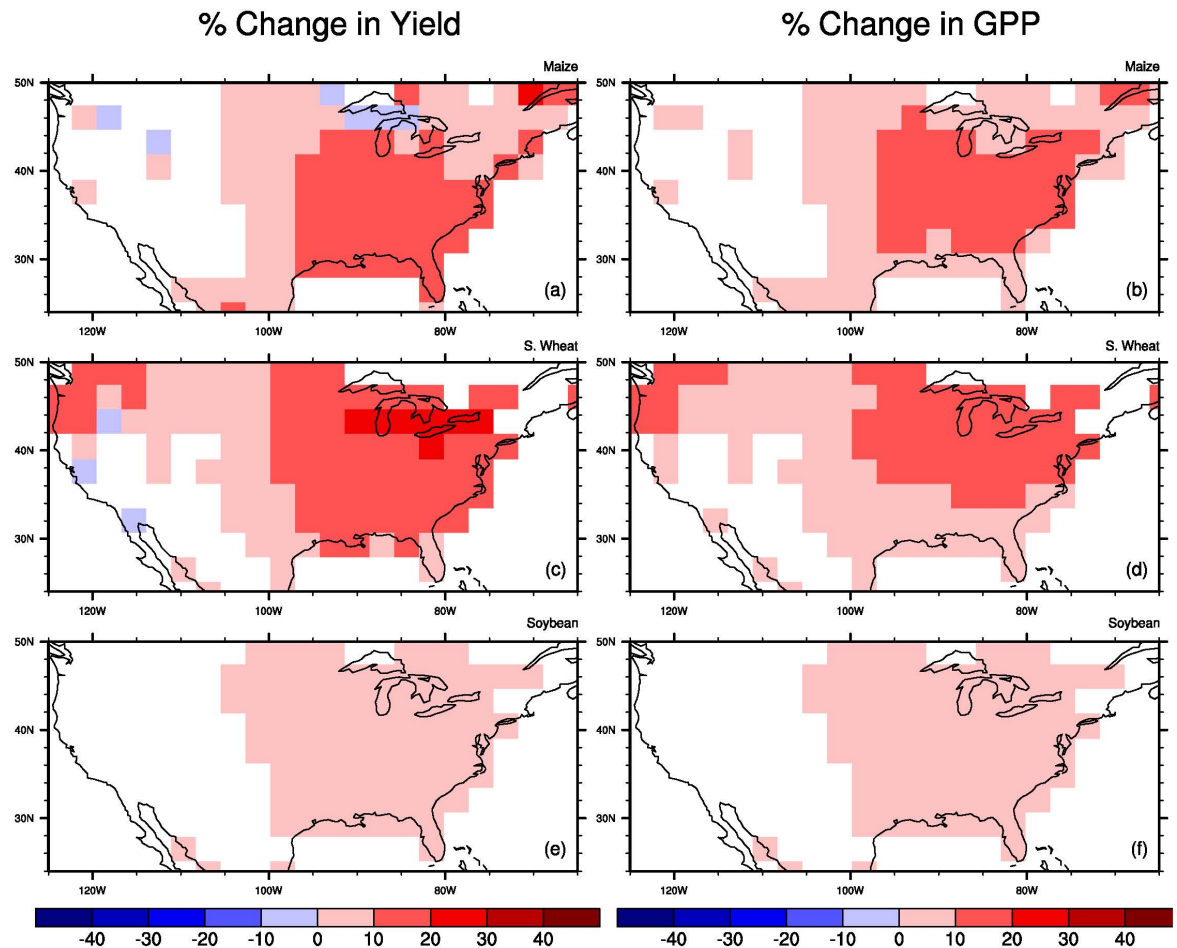

Fig. 11. The percent change in yield (left column) and GPP (right column) for (a, b) maize, (c, d) spring wheat, and (e, f) soybean from a $70 \%$ residue return management practice (HIGHRES).
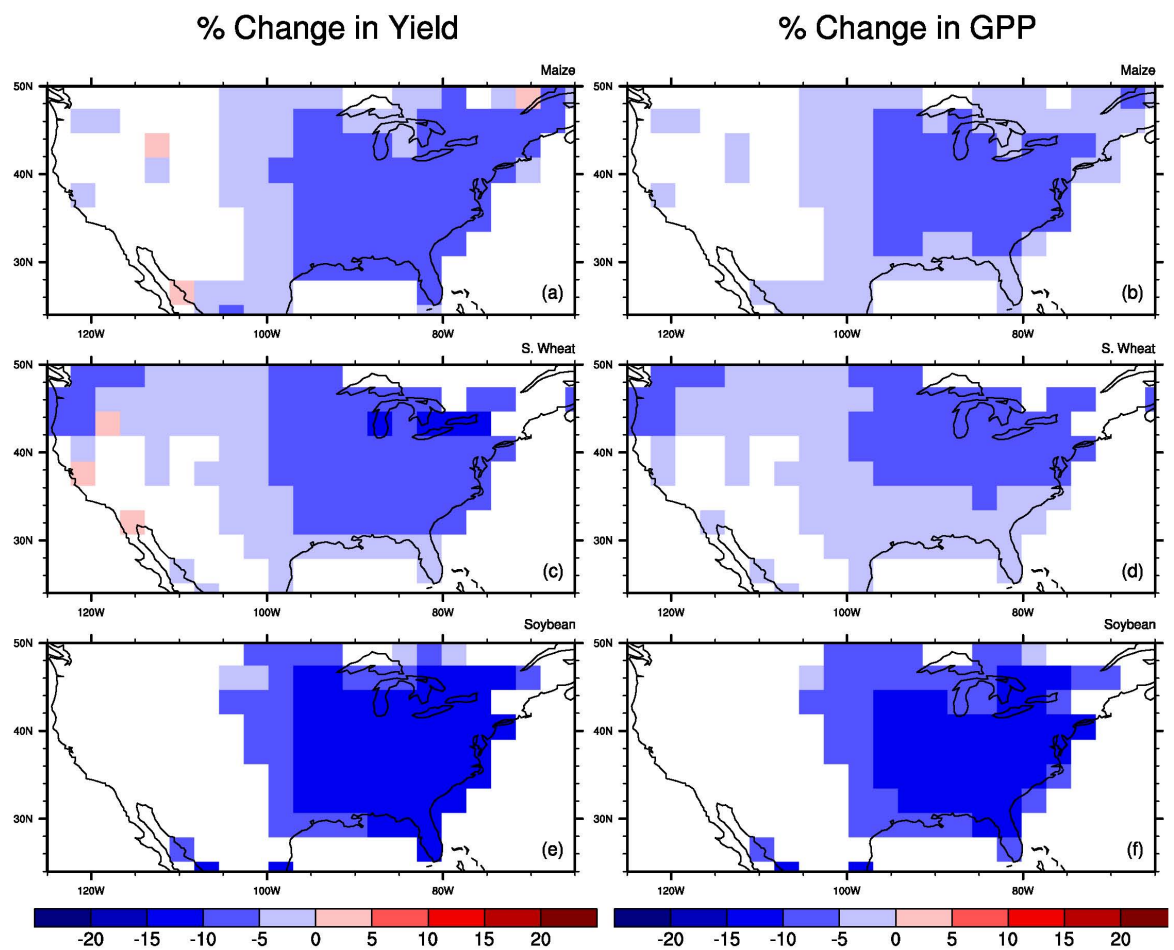

Fig. 12. The percent change in yield (left column) and GPP (right column) for (a, b) maize, (c, d) spring wheat, and (e, f) soybean from a $10 \%$ residue return management practice (LOWRES). 
Change in Plant Date
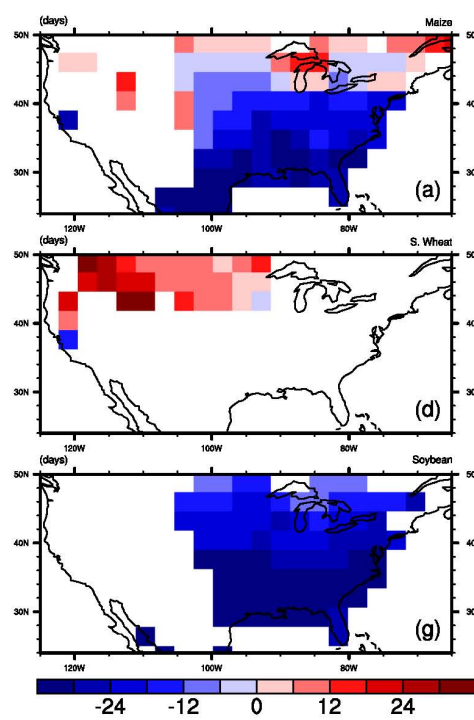

Change in Crop Yield
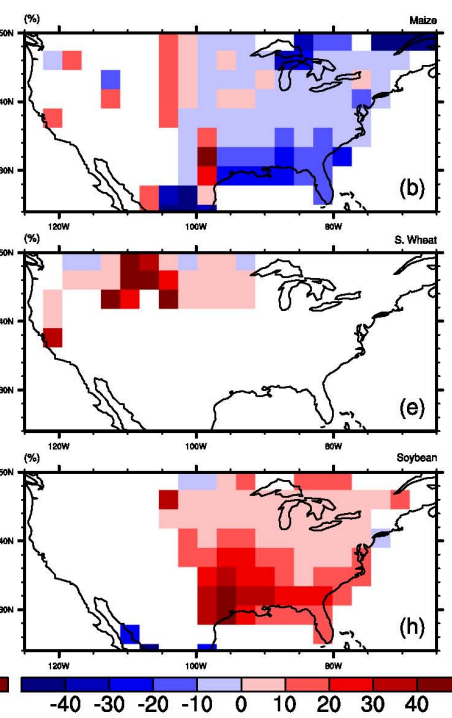

Change in GPP
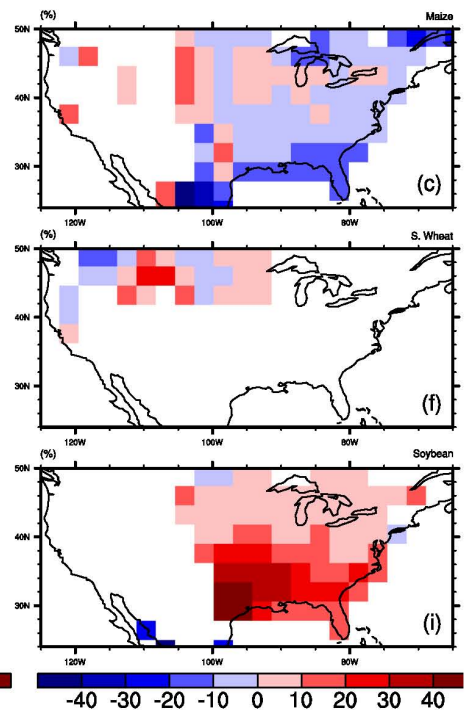

Fig. 13. The left column is the change in planting date (days), represented by the difference between LowPTEMP and CROP for (a) maize, (d) spring wheat, and (g) soybean. The center and right columns are the percent change in crop yield for (b) maize, (e) spring wheat, and (h) soybean and the GPP for (c) maize, (f) spring wheat, and (i) soybean resulting from new planting dates.

\section{Change in Plant Date}
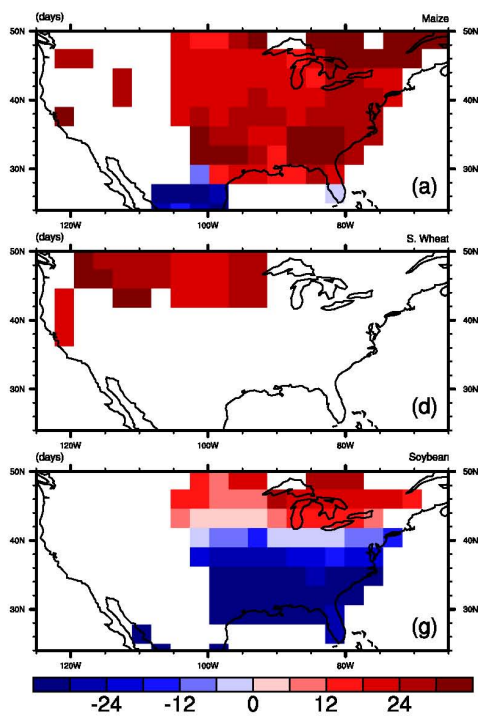

Change in Crop Yield
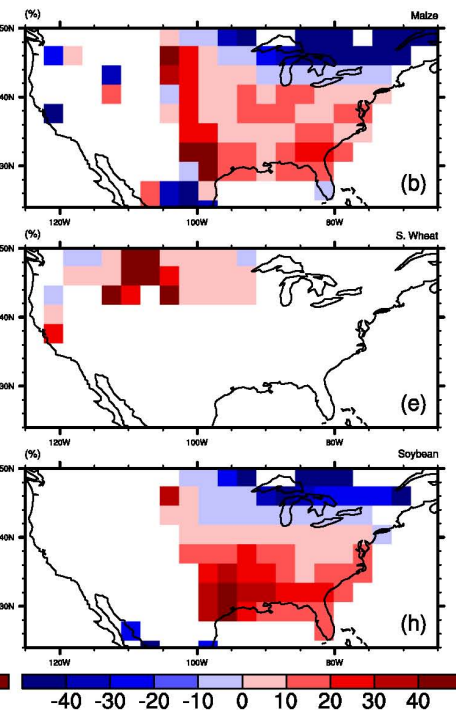

Change in GPP
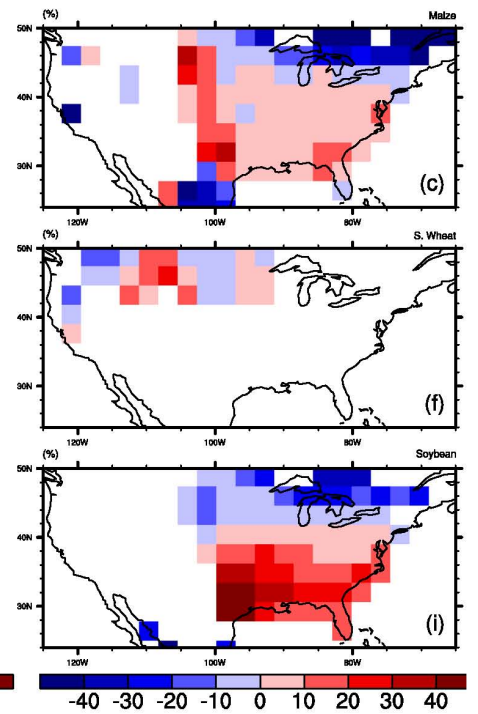

Fig. 14. The left column is the change in planting date (days), represented by the difference between HighPTEMP and CROP for (a) maize, (d) spring wheat, and (g) soybean. The center and right columns are the percent change in crop yield for (b) maize, (e) spring wheat, and (h) soybean and the GPP for (c) maize, (f) spring wheat, and (i) soybean resulting from new planting dates.

yields increased in both hemispheres, but the SH experienced a much larger increase. Again, differences between the two hemispheres are expected, because planting temperatures are more appropriate for the NH.

For the United States, planting dates for maize are generally later than average fixed planting dates in CROP (Fig. 14). We found that the temperature threshold for maize was too high and that the model assumed planting on the default last planting date. The result of later planting was an increase in crop yield and GPP, as shown in Fig. 14. We believe that this is again the result of the model treatment of nitrogen. The LAI (not shown) was larger in HighPTEMP, allowing more carbon assimilation during grain development for increased yield. Longer day length likely allowed increased carbon 
assimilation during the fertilizer application period, which benefited the crop throughout the growth period. Wheat was planted slightly later, but, like the LowPTEMP condition, it showed little sensitivity to planting date other than a slight increase in yields in most areas (Fig. 14). Soybean was still planted early in the southern United States but was planted later in the northern United States. The resulting change in yield is still an increase in the South, but a decrease in yield occurs with later planting. Soybean fixation (not shown) increased in the South but decreased in the North (where decreases in yield occurred). Most of the decreases in the North were the result of insufficient PHU accumulation to reach maturity prior to the onset of the cool season resulting in an automatic harvest.

\section{Discussion}

Cultivation has serious effects on the terrestrial carbon cycle, and the consequences of land management for carbon fluxes have only recently been included in earlier land surface modeling within the CLM framework (Levis et al., 2012). Previous versions of CLM had either a crude representation of crops or omitted many traits that are important, such as fertilizer, soybean fixation, and retranslocation. CLM-Crop, which can assess the impacts of several crop types on biogeochemical cycles, has been evaluated for the United States by using field measurement data for maize and soybean systems. Although the model does well in representing appropriate responses for agriculture systems, including improving the global simulated GPP fluxes, remaining inconsistencies include decreased GPP for maize during the middle of the growth period and overestimated yields for soybean and wheat. Improvements to the nitrogen scheme in the model, including a more complex fertilizer application and denitrification factor, might help to correct disagreements between the model output and observations.

CLM-Crop simulations agree with other crop models in predicting a negative correlation between yield and temperature and a positive correlation between yield and precipitation. This has important implications, indicating that as climate shifts, crop yields might be expected to decline. This result could be amplified when extreme weather events including drought, heat waves, and heavy precipitation events are taken into account, as predicted by the Intergovernmental Panel on Climate Change (Meehl et al., 2007).

Residue management can have strong implications for yield and productivity, as shown by CLM-Crop. Increasing the amount of plant harvested for use as animal bedding, feed, or biomass fuel can influence below-ground biogeochemistry cycling, which impacts soil quality and therefore future yields. Because few statistics on residue management exist, application of this management practice is difficult to implement; however, the sensitivity of yield to the amount of residue left on the field as simulated by CLM-Crop demon- strates that residue is an important consideration for sustainable cultivation. As below-ground carbon and nitrogen cycling are improved in CLM, dependence of crop productivity on nutrient availability from residue management should decrease, although sensitivity to decomposition and turnover will still remain.

Both the HighPTEMP and LowPTEMP simulations show that the model has a high sensitivity to the planting date, because of the influence of planting date on timing of growth. The most important development period during crop growth seems to be in the early stages, when assimilated carbon and nitrogen will influence the remainder of the growth period, particularly because the amount of carbon allocated to leaves decreases with time. Even more notably, the nitrogen cycling in the model has significant influence on crop development. Availability of nitrogen during crucial stages of growth significantly affects how a plant prospers. Improvements in the nitrogen cycling and coupling in the model should enhance nitrogen availability and perhaps limit this sensitivity.

Expanding the model to incorporate other management practices (tillage, irrigation, etc.) is important for future model development. Although the crop representation in CLM-Crop is flexible enough for expansion to a global scale, rigorous testing is needed to ensure that crop behavior is consistent with regional observations. Other additions to the CLM-Crop model should improve the carbon cycling representation. The current CLM framework allows natural vegetation to change with time; however, managed croplands as they are treated in this model cannot expand or contract. Using historical vegetation data to create a transient vegetation data set with appropriate deforestation/reforestation and grassland removal rates related to the growth or abandonment of cultivated land use could improve the performance of CLM-Crop. In addition, our parameter calibration is focused on crop species grown in the United States; expanding these parameters to capture other cultivars grown more broadly would improve the model's ability to capture global crop productivity. One example is to use fertilizer data sets to establish spatial fertilizer application by crop type, such as that developed by Potter et al. (2010).

While the improvements to CLM showed better agreement with above-ground cycling, we have not considered belowground carbon, which is an integral component for proper consideration of the full carbon cycle in an Earth system model. Further research is needed to understand the importance of agro-ecosystems on soil carbon. Soil organic carbon loss can vary greatly, depending on management practices, and including actions such as fertilizer and residue management in modeling studies is important for simulating effects on carbon storage. Incorporating crop representation into CLM is the first step toward evaluating the impacts of land management within an Earth system model. 
Acknowledgements. We would like to extend our thanks to Sam Levis for his helpful discussions and guidance with model development. Our gratitude also goes to Bill Sacks for making the Crop Calendar Dataset available for use as model input. The work of Drewniak, Song, Prell, Kotamarthi, and Jacob at Argonne National Laboratory was supported by the US Department of Energy, Office of Science, under contract DE-AC02-06CH11357. Numerical simulations were performed with resources provided by the National Energy Research Scientific Computing Center, supported by the Office of Science and US Department of Energy Contract No. DE-AC02-05CH11231.

Edited by: M.-H. Lo

\section{References}

Amanullah, M. J. H., Nawab, K., and Ali, A.: Response of Specific Leaf Area (SLA), Leaf Area Index (LAI) and Leaf Area Ratio (LAR) of maize (Zea mays L.) to plant density, rate and timing of nitrogen application, World Appl. Sci. J., 2, 235-243, 2007.

Amos, B. and Walters, D. T.: Maize root biomass and net rhizodeposited carbon, Soil Sci. Soc. Am. J., 70, 1489-1503, 2006.

Araki, H. and Iijima, M.: Deep rooting in winter wheat: rooting nodes of deep roots in two cultivars with deep and shallow root system, Plant Prod. Sci., 4, 215-219, 2001.

Barbottin, A., Lecomte, C., Bouchard, C., and Jeuffroy, M.-H.: Nitrogen remobilization during grain filling in wheat: Genotypic and environmental effects, Crop Sci., 45, 1141-1150, 2005.

Batjes, N. H.: ISRIC-WISE harmonized global soil profile dataset (Ver. 3.1). Report 2008/02, ISRIC - World Soil Information, Wageningen, 2008.

Blanco-Canqui, H. and Lal, R.: No-tillage and soil-profile carbon sequestration: an on-farm assessment, Soil Water Manag. Conservation, 72, 693-701, 2008.

Bonan, G. B., Levis, S., Kergoat, L., and Oleson, K. W.: Landscapes as patches of plant functional types: An integrating concept for climate and ecosystem models, Global Biogeochem. Cy., 16, 1021, doi:10.1029/2000GB001360, 2002.

Bondeau, A., Smith, P. C., Zaehle, S., Schaphoff, S., Lucht, W., Cramer, W., Gerten, D., Lotze-Campen, H., Mullers, C., Reichstein, M., and Smith, B.: Modeling the role of agriculture for the $20^{t h}$ century global terrestrial carbon balance, Global Change Biol., 13, 679-706, 2007.

Crawford, T. W., Rendig, V. V., and Broadent, F. E.: Sources, fluxes, and sinks of nitrogen during early reproductive growth of maize (Zea mays L.), Plant Physiol., 70, 1645-1660, 1982.

Diffenbaugh, N. S.: Influence of modern land cover on the climate of the United States, Climate Dynam., 33, 945-958, 2009.

Dou, F. and Hans, F. M.: Tillage and nitrogen effects on soil organic matter fractions in wheat-based systems, Soil Sci. Soc. Am. J., 70, 1896-1905, 2006.

Fargione, J., Hill, J., Tilman, D., Polasky, S., and Hawthorne, P.: Land clearing and the biofuel carbon debt, Science, 319, 12351238, 2008.

Fischer, G., Shah, M., Tubiello, F. N., and van Velhuizen, H.: Socioeconomic and climate change impacts on agriculture: an integrated assessment, 1990-2080, Philos. T. R. SOC. A, 360, 20672083, 2005.
Gallais, A., Coque, M. Quillere, I., Prioul, J., and Hirel, B.: Modeling postsilking nitrogen fluxes in maize (Zea mays) using ${ }^{15} \mathrm{~N}$ labeling field experiments, New Phytol., 172, 696-707, 2006.

Gallais, A., Coque, M., Gouis, J. L., Prioul, J. L., Hirel, B., and Quillere, I.: Estimating the proportion of nitrogen remobilization and of postsilking nitrogen uptake allocated to maize kernels by Nitrogen-15 labeling, Crop Sci., 47, 685-693, 2007.

Garay, A. F. and Wilhelm W. W.: Root system characteristics of two soybean isolines undergoing water stress conditions, Agronomy J., 75, 973-977, 1983.

Gibbs, H. K., Johnston, M., Foley, J. A., Holloway, T., Monfreda, C., Ramankutty, N., and Zaks, D.: Carbon payback times for crop-based biofuel expansion in the tropics: the effects of changing yield and technology, Environ. Res. Lett., 3, 034001, doi:10.1088/1748-9326/3/3/034001, 2008.

Hooker, B. A., Morris, T. F., Peters, R., and Cardon, Z. G.: Longterm effects of tillage and corn stalk return on soil carbon dynamics, Soil Sci. Soc. Am. J., 69, 188-196, 2005.

Huggins, D. R., Allmaras, R. R., Clapp, C. E., Lamb, J. A., and Randall, G. W.: Corn-soybean sequence and tillage effects on soil carbon dynamics and storage, Soil Sci. Soc. Am. J., 71, 145-154, 2007.

Hurtt, G. C., Frolking, S., Fearon, M. G., Moore, B., Shevliakova, E., Malyshev, S., Pacala, S. W., and Houghton, R. A.: The underpinnings of land-use history: three centuries of global gridded land-use transitions, wood harvest activity, and resulting secondary lands, Global Change Biol., 12, 1208-1229, 2006.

Jobbagy, E. G. and Jackson, R. B.: The distribution of soil nutrients with depth: Global patterns and the imprint of plants, Biogeochemistry, 53, 51-77, 2001.

Kalnay, E., Kanamitsu, M., Kistler, R., Collins, W., Deaven, D., Gandin, L., Iredell, M., Saha, S., White, G., Woolen, J., Zhu, Y., Chelliah, M., Ebisuzaki, W., Higgins, W., Janowiak, J., Mo, K. C., Ropelewski, C., Wang, J., Leetmaa, A., Reynolds, R., Jenne, R., and Joseph, D.: The NCEP/NCAR 40-year reanalysis project, Bull. Amer. Meteor. Soc., 77, 437-470, 1996.

Khan, S. A., Mulvaney, R. L., Ellsworth, T. R., and Boast, C. W.: The myth of nitrogen fertilization for soil carbon sequestration, J. Environ. Qual, 36, 1821-1832, 2007.

Kim, H., Kim, S., and Dale, B. E.: Biofuels, land use change, and greenhouse gas emissions: Some unexplored variables, Environ. Sci. Technol., 43, 961-967, 2009.

Kucharik, C. J.: Evaluation of a process-based agro-ecosystem model (Agro-IBIS) across the US Corn Belt: Simulations of the interannual variability in maize yield, Earth Interact., 7, 1-33, 2003.

Kucharik, C. J.: Contributions of planting date trends to increased maize yields in the Central United States, Agronomy J., 100, 328-336, 2008.

Kucharik, C. J. and Brye, K. R.: Integrated BIosphere Simulator (IBIS) Yield and Nitrate Loss Predictions for Wisconsin Maize Receiving Varied Amounts of Nitrogen Fertilizer, J. Environ. Qual., 32, 247-268, 2003.

Kucharik, C. J. and Twine, T. E.: Residue, respiration, and residuals: Evaluation of a dynamic agroecosystem model using eddy flux measurements and biometric data, Agr. Forest Meteorol., 146, 134-158, 2007.

Leff, B., Ramankutty, N., and Foley, J. A.: Geographic distribution of major crops across the world, Global Biogeochem. Cy., 18, 
GB1009, doi:10.1029/2003GB002108, 2004.

Levis, S., Bonan, G. B., Kluzek, E., Thornton, P. E., Jones, A., Sacks, W. J., Kucharik, C. J.: Interactive Crop Management in the Community Earth System Model (CESM1): seasonal influences on land-atmosphere fluxes, J. Climate, 25, doi:10.1175/JCLI-D11-00446.1, 2012.

Lobell, D. B., Bala, G., and Duffy, P. B.: Biogeophysical impacts of cropland management changes on climate, Geophys. Res. Lett., 33, L06708, doi:10.1029/2005GL025492, 2006.

Lobell, D. B. and Field, C. B.: Global scale climate-crop yield relationships and the impacts of recent warming, Environ. Res. Lett., 2, 014002, doi:10.1088/1748-9326/2/1/014002, 2007.

Lobell, D. B., Schlenker, W., and Costa-Roberts, J.: Climate trends and global crop production since 1980, Science, 333, 616-620, 2011.

Mayaki, W. C., Reare, I. D., and Stone L. R.: Top and root growth of irrigated and non-irrigated soybean, Crop Sci., 16, 92-94, 1976.

Meehl, G. A., Stocker, T. F., Collins, W. D., Friedlingstein, P., Gaye, A. T., Gregory, J. M., Kitoh, A., Knutti, R., Murphy, J. M., Noda, A., Raper, S. C. B., Watterson, I. G., Weaver, A. J., and Zhao, Z.C.: Global Climate Projections. In: Climate Change 2007: The Physical Science Basis, in: Contribution of Working Group I to the Fourth Assessment Report of the Intergovernmental Panel on Climate Change, edited by: Solomon, S., Qin, D., Manning, M., Chen, Z., Marquis, M., Averyt, K. B., Tignor, M., and Miller, H. L., Cambridge University Press, Cambridge, United Kingdom and New York, NY, USA, 747-845, 2007.

Monfreda, C., Ramankutty, N., and Foley, J. A.: Farming the planet: 2. Geographic distribution of crop areas, yields, physiological types, and net primary production in the year 2000, Global Biogeochem. Cy., 22, GB1022, doi:10.1029/2007GB002947, 2008.

Neitsch, S. L., Arnold, J. G., Kiniry, J. R., and Williams J. R.: Soil and Water Assessment Tool, Theoretical Documentation: Version 2005. Temple, TX. USDA Agricultural Research Service and Texas A\&M Blackland Research Center, 2005.

New, M., Hulme, M., and Jones, P. D.: Representing TwentiethCentury Space-Time Climate Variability. Part I: Development of a 1961-90 Mean Monthly Terrestrial Climatology, J. Climate, 12, 829-856, 1999.

Oleson, K. W., Dai, Y., Bonan, G., Bosilovich, M., Dickinson, R., Dirmeyer, P., Hoffman, F., Houser, P., Levis, S., Niu, G.Y., Thornton, P., Vertenstein, M., Yang, Z.-L., and Zeng, X.: Technical Description of the Community Land Model (CLM). NCAR/TN-461+STR, National Center for Atmospheric Research, Boulder, Colorado, 2004.

Oleson, K. W., Niu, G.-Y., Yang, Z.-L., Lawrence, D. M., Thornton, P. E., Lawrence, P. J., Stockli, R., Dickinson, R. E., Bonan, G. B., Levis, S., Dai, A., and Qian, T.: Improvements to the Community Land Model and their impact on the hydrological cycle, J. Geophys. Res., 113, G01021, doi:10.1029/2007JG000563, 2008.

Osborne, T. M., Lawrence, D. M., Challinor, A. J., Slingo, J. M., and Wheeler, T. R.: Development and assessment of a coupled crop-climate model, Global Change Biol., 13, 169-183, 2007.

Osborne, T., Slingo, J., Lawrence, D., and Wheeler, T.: Examining the interaction of growing crops with local climate using a coupled crop-climate model, J. Climate, 22, 1393-1411, 2009.

Papale, D. and Valentini, R.: A new assessment of European forests carbon exchanges by eddy fluxes and artificial neural network spatialization, Global Change Biol., 9, 525-535, 2003.
Parry, M. L., Rosenzweig, C., Iglesias, A., Livermore, M., and Fischer, G: Effects of climate change on global food production under SRES emissions and socio-economic scenarios, Global Environ. Change, 14, 53-67, 2004.

Pollmer, W. G., Eberhard, D., Klein, D., and Dhillon, B. S.: Genetic control of nitrogen uptake and translocation in maize, Crop Sci., 19, 82-86, 1979.

Potter, P., Ramankutty, N., Bennett, E. M., and Donner, S. D.: Characterizing the spatial patterns of global fertilizer application and manure production, Earth Interact., 14, 1-22, doi:10.1175/2009EI288.1, 2010.

Reichstein, M., Falge, E., Baldocchi, D., Papale, D., Aubinet, M., Berbigier, P., Bernhofer, C., Buchmann, N., Gilmanov, T., Grainer, A., Grunwald, T., Havrankova, K., Ilvesniemi, H., Janous D., Knohl, A., Laurila, T., Lohila, A., Loustau, D., Matteucci, G., Meyers, T., Miglietta, F., Ourcival, J.-M., Pumpanen, J., Rambal, S., Rotenberg, E., Sanz, M., Tenhunen, J., Seufert, G., Vaccari, F., Vesala, T., Yakir, D., and Valentini, R.: On the separation of net ecosystem exchange into assimilation and ecosystem respiration: review and improved algorithm, Global Change Biol., 11, 1424-1439, 2005.

Rosenzweig, C., Tubiello, F. N., Goldberg, R, Mills, E., and Bloomfield, J.: Increased crop damage in the US from excess precipitation under climate change, Global Environ. Change, 12, 197202, 2002.

Sacks, W. J., Deryng, D., Foley, J. A., and Ramankutty, N.: Crop planting dates: an analysis of global patterns, Global Ecol. Biogeogr., 19, 607-620, doi: 10.1111/j.1466-8238.2010.00551.x, 2010.

Schlenker, W. and Roberts, M. J.: Nonlinear temperature effects indicate severe damages to US crop yields under climate change, Proc. National Academy Sci., 106, 15594-15598, 2009.

Searchinger, T., Heimlick, R., Houghton, R. A., Dong, F., Elobeid, A., Fabiosa, J., Tokgoz, S., Hayes, D., and Yu, T.-H.: Use of US croplands for biofuels increases greenhouse gases through emissions from land use change, Science, 319, 1238-1240, 2008.

Simpson, R. J., Lambers, H., and Dalling, M. J.: Nitrogen redistribution during grain growth in wheat (Triticum avestivum L.), Plant Physiol., 71, 7-14, 1983.

Smith, P. C., De Noblet-Decoudre, N., Ciais, P., Peylin, P., Viovy, N., Meurdesoif, Y., and Bondeau, A.: European-wide simulations of croplands using an improved terrestrial biosphere model: Phenology and productivity, J. Geophys. Res., 115, G01014, doi:10.1029/2008JG000800, 2010.

Stockli, R., Lawrence, D. M., Niu, G.-Y., Oleson, K. W., Thornton, P. E., Yang, Z.-L., Bonan, G. B., Denning, A. S., and Running, S. W.: Use of FLUXNET in the Community Land Model development, J. Geophys. Res., 113, G01025, doi:10.1029/2007JG000562, 2008.

Ta, C. T. and Weiland, R. T.: Nitrogen partitioning in maize during ear development, Crop Sci., 32, 443-451, 1992.

Tang, J. Y., Riley, W. J., Koven, C. D., and Subin, Z. M.: CLM4BeTR, a generic biogeochemical transport and reaction module for CLM4: model development, evaluation, and application, Geosci. Model Dev., 6, 127-140, doi:10.5194/gmd-6-127-2013, 2013.

Tardieu, F., Granier, C., and Muller, B.: Modelling leaf expansion in a fluctuating environment: are changes in specific leaf area a consequence of changes in expansion rate?, New Phytologist, 
143, 33-43, 1999.

Thornton, P. E. and Rosenbloom, N.: Ecosystem model spin-up: estimating steady state conditions in a coupled terrestrial carbon and nitrogen cycle model, Ecol. Model., 189, 25-48, 2005.

Thornton, P. E. and Zimmerman, N. E.: An improved canopy integration scheme for a land surface model with prognostic canopy structure, J. Climate, 20, 3902-3923, 2007.

Urban, D., Roberts, M. J., Schlenker, W., and Lobell, D. B.: Projected temperature changes indicate significant increase in interannual variability of US maize yields, Climatic Change, 112, 525-533, 2012.
West, T. O. and Post, W. M.: Soil organic carbon sequestration rates by tillage and crop rotation: a global data analysis, Soil Sci. Soc. Am. J., 66, 1930-1946, 2002.

Zhao, M., Heinsch, F. A., Nemani, R. R., and Running, S. W.: Improvements of the MODIS terrestrial gross and net primary production global data set, Remote Sens. Environ., 95, 164-176, 2005. 